\title{
A holistic framework integrating plant-microbe-mineral regulation of soil bioavailable nitrogen
}

\author{
Amanda B. Daly (1) - Andrea Jilling (1) - Timothy M. Bowles (D) Robert W. Buchkowski (D) \\ Serita D. Frey (D) Cynthia M. Kallenbach (D) Marco Keiluweit (D) \\ Maria Mooshammer (D) - Joshua P. Schimel $(\mathbb{D} \cdot$ - A. Stuart Grandy $(\mathbb{D}$
}

Received: 18 November 2020/Accepted: 6 April 2021 / Published online: 6 May 2021

(C) The Author(s) 2021

\begin{abstract}
Soil organic nitrogen $(\mathrm{N})$ is a critical resource for plants and microbes, but the processes that govern its cycle are not well-described. To promote a holistic understanding of soil $\mathrm{N}$ dynamics, we need an integrated model that links soil organic matter (SOM) cycling to bioavailable $\mathrm{N}$ in both unmanaged and managed landscapes, including agroecosystems. We present a framework that unifies recent conceptual advances in our understanding of three critical steps in bioavailable $\mathrm{N}$ cycling: organic $\mathrm{N}$ (ON) depolymerization and solubilization; bioavailable $\mathrm{N}$ sorption and desorption on mineral surfaces;
\end{abstract}

Responsible Editor: Sujay Kaushal.

This paper is an invited contribution to the 35thAnniversary Special Issue, edited by Sujay Kaushal, Robert Howarth,and Kate Lajtha

Supplementary Information The online version contains supplementary material available at https://doi.org/10.1007/ s10533-021-00793-9.

A. B. Daly · S. D. Frey · A. S. Grandy $(\varangle)$

Department of Natural Resources and the Environment, University of New Hampshire, 56 College Road, Durham, NH 03824, USA

e-mail: stuart.grandy@unh.edu

A. Jilling

Department of Plant and Soil Sciences, Oklahoma State University, Stillwater, OK, USA and microbial ON turnover including assimilation, mineralization, and the recycling of microbial products. Consideration of the balance between these processes provides insight into the sources, sinks, and flux rates of bioavailable $\mathrm{N}$. By accounting for interactions among the biological, physical, and chemical controls over $\mathrm{ON}$ and its availability to plants and microbes, our conceptual model unifies complex mechanisms of $\mathrm{ON}$ transformation in a concrete conceptual framework that is amenable to experimental testing and translates into ideas for new management practices. This framework will allow researchers and practitioners to use common measurements of particulate organic matter $(\mathrm{POM})$ and mineral-associated organic matter (MAOM) to design strategic organic $\mathrm{N}$-cycle interventions that optimize ecosystem productivity and minimize environmental $\mathrm{N}$ loss.

T. M. Bowles · M. Mooshammer Department of Environmental Science, Policy, and Management, University of California Berkeley, Berkeley, CA, USA

R. W. Buchkowski

Department of Biology, University of Western Ontario,

London, ON, Canada

C. M. Kallenbach

Department of Natural Resource Sciences, McGill

University, Montreal, Canada 
Keywords Depolymerization · Particulate organic matter $\cdot$ Mineral associated organic matter $\cdot$ Microbial physiology $\cdot$ Fertilizer

$\begin{array}{ll}\text { Abbreviations } \\ \text { AA } & \text { Amino acid } \\ \text { C } & \text { Carbon } \\ \text { CUE } & \text { Carbon use efficiency } \\ & \\ \text { MAOM } & \text { Mineral associated organic matter } \\ \text { N } & \text { Nitrogen } \\ \text { NUE } & \text { Nitrogen use efficiency } \\ \text { ON } & \text { Organic nitrogen } \\ \text { POM } & \text { Particulate organic matter } \\ \text { SOC } & \text { Soil organic carbon } \\ \text { SOM } & \text { Soil organic matter } \\ \text { SON } & \text { Soil organic nitrogen }\end{array}$

\section{Introduction}

Nitrogen (N) is essential for life as a key constituent of biomolecules including DNA, RNA, chlorophyll, and enzymes. In soil, bioavailable $\mathrm{N}$ is comprised of dissolved inorganic and organic $\mathrm{N}$-including small polymers and monomers - that can be assimilated by plants and/or microbes. Supplies of bioavailable soil N sometimes exceed plant requirements, but often fail to meet them, resulting in $\mathrm{N}$ asynchrony that constrains ecosystem productivity and exacerbates environmental nutrient losses, which are expected to intensify under climate change (Sinha et al. 2017; Bowles et al. 2018; Houlton et al. 2019; Dai et al. 2020). This "N problem" arises in part because of nitrogen's changeable nature: as a reactive element found in multiple forms and seven oxidation states, $\mathrm{N}$ is difficult to track and manage.

M. Keiluweit

School of Earth \& Sustainability and Stockbridge School of Agriculture, University of Massachusetts, Amherst, MA, USA

J. P. Schimel

Department of Ecology, Evolution, and Marine Biology, University of California, Santa Barbara,

CA, USA
Unresolved issues in intensively managed agroecosystems epitomize our incomplete understanding of bioavailable $\mathrm{N}$. In these systems, the persistent challenge of minimizing $\mathrm{N}$ losses and improving the spatial and temporal match between $\mathrm{N}$ availability and plant $\mathrm{N}$ demand (i.e. $\mathrm{N}$ synchrony) derives in part from a historical focus on the inorganic $\mathrm{N}$ pool. Even with high synthetic $\mathrm{N}$ inputs, however, a substantial fraction of inorganic $\mathrm{N}$ is derived from the soil organic matter pool (Yan et al. 2020). Yet, we remain without a universal and accurate assay or model that can predict organic $\mathrm{N}(\mathrm{ON})$ conversion to plant-available inorganic $\mathrm{N}$, despite the long-acknowledged need for one (e.g. Vitousek 1982; Schimel and Bennett 2004) and continuing efforts to develop a suitable $\mathrm{N}$ availability index (Ros 2012; Curtin et al. 2017; Clivot et al. 2017; McDaniel et al. 2020).

A focus on inorganic $\mathrm{N}$ pools overlooks the important mechanisms occurring in soil that determine how much $\mathrm{ON}$ feeds into and supplies the inorganic $\mathrm{N}$ pool. Moreover, the ON component of the bioavailable $\mathrm{N}$ pool is itself a critical $\mathrm{N}$ source to plants and microbes. Estimates of bioavailable $\mathrm{N}$ that do include ON usually represent it as the short-term potentially mineralizable $\mathrm{N}$ pool. However, this pool is operationally defined; in measuring net changes in inorganic $\mathrm{N}$ under optimized conditions and in the absence of live plant roots, potentially mineralizable $\mathrm{N}$ often poorly explains the variability in outcomes such as crop yields, estimated or actual crop $\mathrm{N}$ availability, and fertilizer needs (Fox and Piekielek 1984; Thicke et al. 1993; Curtin and McCallum 2004; DessureaultRompré et al. 2014; McDaniel et al. 2020). Agricultural practitioners currently rely on $\mathrm{N}$-credit calculators that do not explicitly consider soil processes and interactions (Lory et al. 1995) and are prone to uncertainty, bias, and error (Sharma and Bali 2018). The struggle to quantify the pool of plant- and microbe-accessible $\mathrm{N}$ arises from conceptual gaps in current explanations about the fundamental mechanisms that drive $\mathrm{N}$ bioavailability; these stem in large part from failing to accurately account for the organic component of the soil $\mathrm{N}$ cycle and its biogeochemical drivers.

The need to emphasize organic $\mathrm{N}$ is reminiscent of the impetus that led to developments in how the soil organic carbon (SOC) cycle is conceptualized. In the twentieth century, researchers theorized that the inherent chemical recalcitrance of carbon (C) to 
decomposition controlled SOC turnover, but evidence from the last two or more decades reveals that microbes can degrade even the most complex molecules (Gleixner et al. 2001, 2002; Rasse et al. 2006) and that, in the context of overall soil organic matter (SOM) dynamics, recalcitrance only temporarily controls microbial SOC processing rates. Instead, SOC persistence largely emerges from constraints that the soil mineral matrix imposes on microbial access to substrates (Kleber et al. 2011; Schimel and Schaeffer 2012) and SOC dynamics are better predicted by biological and physical controls on $\mathrm{C}$ transfer between different SOC pools (Six et al. 2006; Grandy and Neff 2008), motivating several recent soil $\mathrm{C}$ cycling models to explicitly incorporate soil physical fractions (Sulman et al. 2014; Wieder et al. 2015; Abramoff et al. 2018; Kyker-Snowman et al. 2019). The fate of ON similarly relies on how associations with minerals regulate access to $\mathrm{N}$-containing molecules (Lavallee et al. 2020) which are in turn regulated by biologically mediated chemical and physical processes that have yet to be integrated into the soil $\mathrm{N}$ paradigm (Darrouzet-Nardi and Weintraub 2014).

Here, we aim to unify advances in the understanding of $\mathrm{N}$ transformations by developing a new, testable conceptual model of organic bioavailable $\mathrm{N}$ in soil. We ground our model in two commonly measured SOM pools: particulate organic matter (POM) and mineral-associated organic matter (MAOM), capturing the importance of both the depolymerization of N-containing molecules (Schimel and Bennett 2004) and mineral sorption-desorption (Sollins et al. 1996; Jilling et al. 2018). We highlight how microbial physiological traits shape the fate of $\mathrm{N}$ once it is taken up by microbes. Finally, consistent with Drinkwater and Snapp's (2007) agroecosystem N model and insights into priming mechanisms (e.g. Cheng and Coleman 1990; Dijkstra and Cheng 2007; Phillips et al. 2012; Zhu et al. 2014), we explicitly address the role of plants and their interactions with minerals and microbes in mobilizing N. Below we outline our new model, synthesize relevant new data, and examine some implications of our model in fertilized agroecosystems, aggrading and degrading soils, and under a changing global climate.

\section{Bioavailable nitrogen: conceptual model}

As with previous conceptual frameworks, our model (Fig. 1) traces the flow of $\mathrm{N}$ from SOM through bioavailable ON (via depolymerization; Schimel and Bennett 2004) to microbial biomass and finally into inorganic $\mathrm{N}$ via mineralization. While depolymerization can limit the overall rate of SON cycling, here we focus on its role in supplying $\mathrm{N}$ directly to MAOM and indirectly to MAOM through microbes. Importantly, our model separately considers POM and MAOM; this establishes sorption and desorption as an important sink and source of bioavailable N. MAOM forms through associations with the mineral matrix where mineral properties: (i) determine the chemistry and stability of these organo-mineral interactions (e.g. Parfitt et al. 1997; Baldock and Skjemstad 2000; Krull et al. 2004; Grandy et al. 2009; Abelenda et al. 2011; Buurman and Roscoe 2011); (ii) dictate each soil's potential to accumulate SOM; and (iii) regulate the sorption/desorption dynamics that govern the supply of bioavailable $\mathrm{N}$ from MAOM. Nitrogen from microbial biomass can recycle back into bioavailable $\mathrm{N}$ and SOM, providing a mechanism for soil $\mathrm{N}$ retention and reuse. We thus detail how the physiology of soil microbial communities shapes the amount and partitioning of $\mathrm{N}$ flow between bioavailable $\mathrm{N}$, microbial biomass, MAOM, and inorganic $\mathrm{N}$ through uptake, assimilation, recycling, and mineralization.

The proportion of bioavailable $\mathrm{N}$ derived from POM or MAOM (Fig. 2) depends on the ratio between $\mathrm{N}$ mobilized from $\mathrm{POM}$, via depolymerization and solubilization, versus the potential for mineral sorption. The latter arises from the properties of soil colloids, soil texture, and the overall chemistry and quantity of MAOM and $\mathrm{N}$ in the soil solution (Rillig et al. 2007; Dippold et al. 2014). This framework emphasizes the role of minerals in intercepting, immobilizing, and releasing bioavailable $\mathrm{N}$ via sorption and desorption processes. When mineral sorption potential is high relative to the rate of POM deposition, much of the mobile $\mathrm{N}$ entering MAOM associates strongly with minerals and thus is less able to desorb and become available to plants and microbes. In these conditions, the mineral sorptive potential principally establishes the equilibrium of sorbed vs. dissolved N. As the POM-N supply increases relative to mineral sorption potential, the MAOM pool's likelihood of exchange with the bulk solution increases. At this 
Fig. 1 Conceptual models illustrating current and emerging frameworks of soil bioavailable $\mathrm{N}$ cycling. The emerging model emphasizes three major compartments: (1) depolymerization and solubilization, in grey; (2) interactions between bioavailable organic $\mathrm{N}$ and minerals, in orange, and (3) microbial assimilation, recycling, and mineralization of organic $\mathrm{N}$, in blue. Black arrows represent the direction of $\mathrm{N}$ flow between pools. Green arrows indicate the direction of plant root exudate $\mathrm{C}$ flow. This model does not attempt to capture all steps in the process (see Future Directions). The "current view" is adapted from Schimel and Bennett 2004. (Color figure online)

\section{Current View}

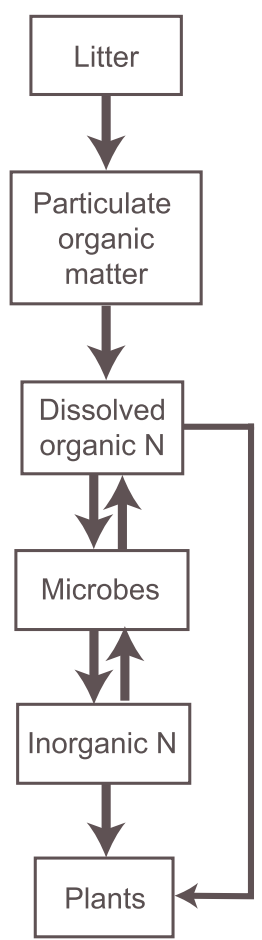

\section{Emerging Framework}

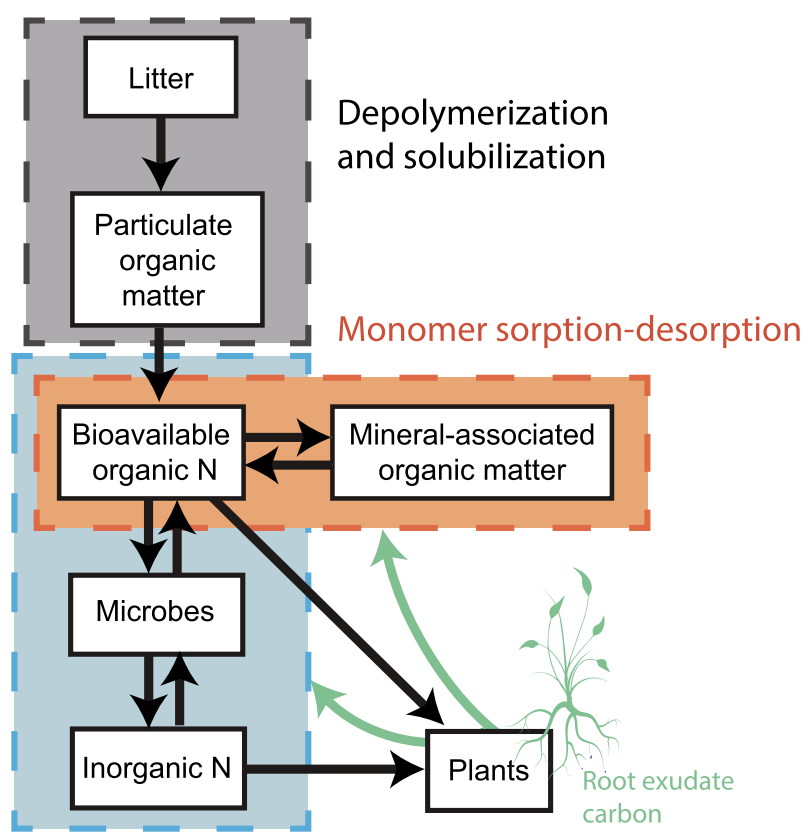

Microbial assimilation, recyling, mineralization stage, MAOM will also include more organic molecules that associate loosely with mineral surfaces or other MAOM and are therefore more accessible to microbes (and, in N-limited systems, plants; e.g. Kleber et al. 2007; Jilling et al. 2018). When high levels of $\mathrm{N}$ supply from POM greatly exceed mineral sorption potential, high concentrations of bioavailable $\mathrm{N}$ from POM result. Some bioavailable MAOM-N exists as a result of exchange with POM-N in solution, but the high concentration of POM-derived bioavailable $\mathrm{N}$ should slow MAOM desorption.

It is worth noting that these bioavailable $\mathrm{N}$ dynamics will be modified by stoichiometry-driven processes like co-metabolism and priming in which, for example, microbes might degrade POM for its $\mathrm{C}$ but MAOM for its $\mathrm{N}$, or might liberate $\mathrm{N}$ from MAOM as a side effect of mining for phosphorus or micronutrients (Blagodatsky et al. 2010; Di Lonardo et al. 2017; Čapek et al. 2018). Our model also incorporates the understanding that plants are not passive players gathering up the leftovers of microbial mineralization; rather, through direct actions and by triggering microbes to act, plants can shape $\mathrm{N}$ cycling (see discussion in Model details: Monomer sorption- desorption). Thus, superimposed on the source-sink dynamics of the POM-N supply and mineral sorption potential, the plant-microbe system can increase MAOM-N provisioning in the rhizosphere (Fig. 2, $N$ from MAOM in the rhizosphere).

How differences in POM and MAOM alter bioavailable $\mathrm{N}$ can be hypothetically illustrated by comparing the contrasting properties of Mollisols and Aridisols. Tallgrass prairie Mollisols of the Central US are characterized by high mineral sorption capacity and a high rate of N supply from POM (Liu et al. 2012; Fig. 2: POM N supply $\approx$ Mineral sorption potential). In these soils, our framework suggests that incoming POM-N will become MAOM, but as bioavailable N supply increases that organic $\mathrm{N}$ will form loose, easily exchangeable associations with other MAOM; while a small portion of POM-derived $\mathrm{N}$ will remain in solution, most bioavailable $\mathrm{N}$ will still come from the more labile fraction of the large MAOM pool. In soils with very high POM inputs or very low sorptive capacity, POM will directly supply the majority of bioavailable N (Fig. 2: POM N supply $>>$ Mineral sorption potential). On the other end of the spectrum (Fig. 2: POM $N$ supply $<<$ Mineral sorption 


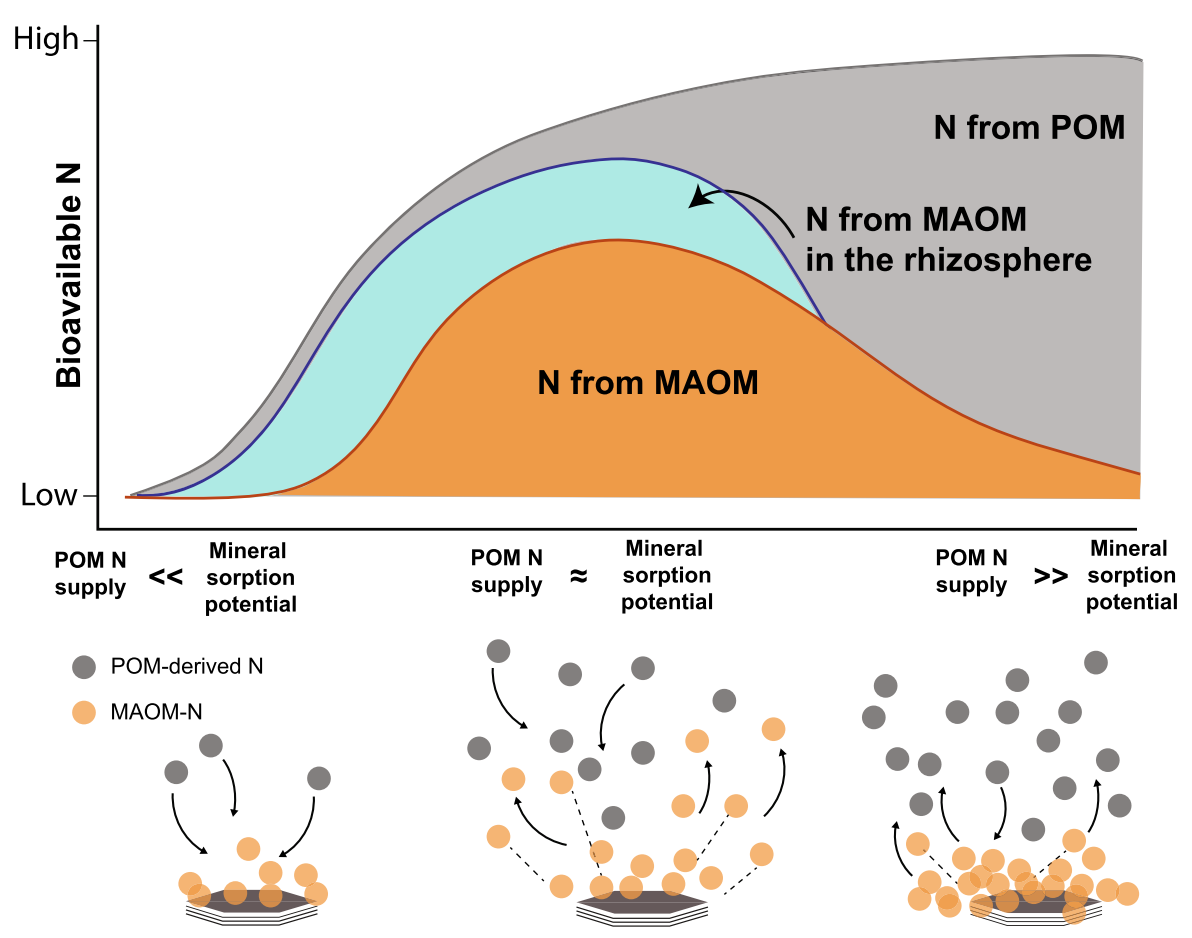

Fig. 2 Conceptual illustration of how soil bioavailable $\mathrm{N}$ and its source (POM vs. MAOM) depend on the ratio of the incoming supply of POM-N to mineral sorption potential, defined as net sorption (i.e. greater gross sorption than gross desorption) of organic N. Stacked curves depict the amount of bioavailable N derived from POM sources (gray), MAOM sources in bulk soil (orange), and MAOM sources under the influence of plantmicrobe interactions in the rhizosphere (turquoise). Low POM $\mathrm{N}$ supply relative to mineral sorption potential (POM N supply $<<$ Mineral sorption potential) will favor sorption and result in low $\mathrm{N}$ bioavailability. Bioavailable $\mathrm{N}$ from MAOM

potential), some Aridisols supply little N from POM; this leaves unfulfilled mineral sorptive capacity and results in meager amounts of bioavailable N. An individual soil's mineral sorption potential can also shift over time as MAOM pools accrete or degrade as a function of variation in POM-N inputs and removal of bioavailable $\mathrm{N}$ from the system by plants, microbes, and environmental losses. We further discuss MAOM and POM dynamics during soil degradation and regeneration in the Applications section of this article. peaks in soils where POM N supply and mineral sorption potential are in relative balance and overall $\mathrm{N}$ bioavailability is moderate-to-high (POM N supply $\approx$ Mineral sorption potential). High relative POM N supply makes POM the principal source of bioavailable $\mathrm{N}$ and results in high $\mathrm{N}$ bioavailability (POM N supply $>>$ Mineral sorption potential). The specific dynamics of bioavailable $\mathrm{N}$ will vary depending on the physical and chemical properties of POM and MAOM, total SOM content, soil mineralogy, and the specific nature of microbial communities and plant-soil interactions. (Color figure online)

\section{Model details}

Depolymerization and solubilization

$\mathrm{N}$ from POM first enters the bioavailable pool when its $\mathrm{N}$-containing polymers break down into soluble organic $\mathrm{N}$ oligomers and monomers, including amino acids (AAs, Fig. 1, grey box). Traditionally, the primary control on $\mathrm{N}$ supply to plants was thought to be the derivation of ammonium $\left(\mathrm{NH}_{4}{ }^{+}\right)$from $\mathrm{ON}$, i.e. $\mathrm{N}$ mineralization, a stance dating to as far back as the late 1800s (Russell and Russell 1950; Harmsen and Van Schreven 1955). In 2004, Schimel and Bennet articulated an emerging consensus that considered depolymerization, rather than inorganic $\mathrm{N}$ production, as the rate-limiting step for $\mathrm{N}$ bioavailability (see also Ladd and Paul 1973). In fact 50-75\% of dissolved ON 


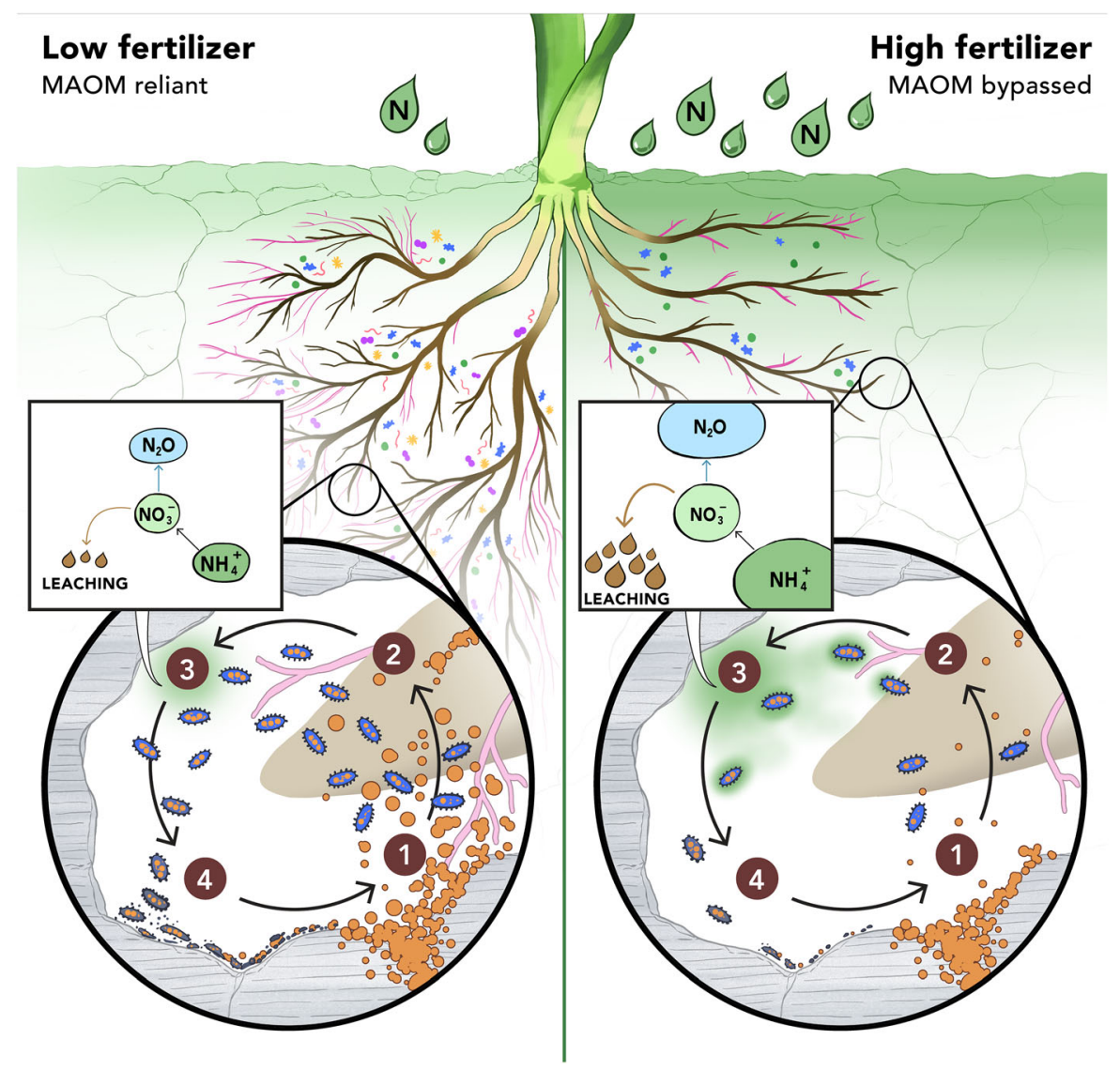

Fig. 3 Potential fertilizer impacts on bioavailable N supply from MAOM in soils with adequate MAOM-N (i.e. Figure 2, POM N supply $\approx$ Mineral sorption potential). Left: Modest, economical fertilizer application (lighter green gradient) incentivizes plants to invest in root production and associations with mycorrhizae (pink). Resulting plant-microbe-mineral interactions in minimally fertilized soils (1) liberate more bioavailable

in soil solution is composed of small, bioavailable peptides and amino acids (Yu et al. 2002). With a halflife of only minutes to hours, free amino acids form a small but very dynamic pool of $\mathrm{ON}$ in soils and plant litter that are quickly taken up by plants and microbes or sorbed to minerals (Kielland et al. 2007; Jones et al. 2009; Wanek et al. 2010; Mooshammer et al. 2012). Microbes consumed free amino acids at a rate $>8$ times greater than ammonium and nitrate during leaf litter decomposition, as measured by a ${ }^{15} \mathrm{~N}-\mathrm{AA}$ pool dilution technique for quantifying gross rates of protein depolymerization and amino acid uptake (Wanek et al. 2010). Other ON monomers, oligomers, and small peptides have similarly rapid turnover (Hill
$\mathrm{N}$ from MAOM (orange); (2) increase microbial biomass; (3) produce less microbial ammonium waste and contribute less to $\mathrm{N}$ losses; and (4) increase necromass inputs that can replenish MAOM-N pools. Right: Heavy fertilizer application (darker green gradient) disrupts these plant-microbe-mineral interactions. (Color figure online)

et al. 2012; Farrell et al. 2013; Hu et al. 2018; Warren 2019; Ma et al. 2020).

New lines of research are exploring the major controls over protein depolymerization and amino acid cycling. Substrate availability limits protein depolymerization in subsoil and plant litter (Mooshammer et al. 2012; Ma et al. 2020), and explained $60-70 \%$ of variation in gross protein depolymerization across several land uses (Noll et al. 2019b). Depolymerization is one strategy by which microbes may acquire $\mathrm{N}$ in response to $\mathrm{N}$ limitation or $\mathrm{C}$ excess: nutrient scarcity induces microbes to preferentially decompose $\mathrm{N}$-bearing polymers from leaf litter (Reuter et al. 2020), and labile C additions increased gross depolymerization rates (Noll 
et al. 2019b). Alternately, depolymerization could be a $\mathrm{C}$ acquisition strategy: in some studies, excess $\mathrm{C}$ lowered amino acid and peptide uptake (Farrell et al. 2014; Yang et al. 2020) and increasing litter C:N was associated with lower rates of gross depolymerization (Mooshammer et al. 2012).

Other evidence contradicts the hypothesis that substrate or nutrient scarcity should increase depolymerization. Substrate concentration was not found to influence breakdown of amino sugar polymers ( $\mathrm{Hu}$ et al. 2018) or other N-containing polymers in topsoil or incubated forest soil (Wild et al. 2019; Ma et al. 2020). Many studies have found no effect of organic or inorganic $\mathrm{N}$ additions on gross soil peptide or amino acid cycling (Farrell et al. 2014; Wild et al. 2019; Noll et al. 2019a; Yang et al. 2020). Inconsistent observations about how stoichiometry relates to depolymerization could be due to the fact that depolymerization products supply microbes with both $\mathrm{C}$ and $\mathrm{N}$, or due to system level microbial community adaptations that alleviate nutrient constraints (Kaiser et al. 2014).

The identity of the decomposers may also influence protein depolymerization. Saprotrophic fungi may degrade $\mathrm{N}$ polymers faster than bacteria (Hobbie and Hobbie 2012) and mycorrhizal fungi can influence decomposition dynamics (Frey 2019). Microbial communities may differ in extracellular protease expression (Puissant et al. 2019), amino acid scavenging (Moe 2013), and cellular peptide transport ( $\mathrm{Li}$ et al. 2020a). Tight microbial recycling of microbial necromass $\mathrm{N}$ could also maintain depolymerization rates regardless of fluctuations in inputs of new substrate (Cissé et al. 2020). Further, the turnover of ON may depend on which forms and chemical structures of ON are available for microbial decomposition (Geisseler and Horwath 2014) and the extent to which interactions with minerals protect substrates from enzymatic attack (Rillig et al. 2007; Wang et al. 2020a). Soil mineral composition has been found to influence gross depolymerization and amino acid cycling rates (Noll et al. 2019b; Hu et al. 2020), and soil physiochemical properties that influence substrate entrapment in small pores and aggregate structures will also regulate the breakdown of $\mathrm{N}$ polymers into bioavailable N (Six et al. 2000; Grandy and Robertson 2007; Smith et al. 2017).
Sorption-desorption of bioavailable organic N

The majority of total soil $\mathrm{N}$ resides in mineralassociated organic matter fractions (Fig. 1, orange box), which are defined based on particle size $(<53$ um) and/or density $\left(<1.7 \mathrm{~g} \mathrm{~cm}^{3}\right)$. MAOM was long considered inaccessible to microbes and plants because radiocarbon data indicate it has very slow average turnover times (centuries to millennia; Fabrizzi et al. 2003; Denef et al. 2013; Paul 2016); therefore, MAOM has been broadly characterized as a sink, and POM as source, of bioavailable N. However, POM fractions store only a small proportion $(<20 \%)$ of total ON in mineral soils and POM can even act as a sink for $\mathrm{N}$ in early stages of decomposition due to its relatively high C:N ratio (Whalen et al. 2000; Fornara et al. 2011; St. Luce et al. 2011). In contrast, MAOM is enriched in microbial products (Schmidt et al. 2011; Miltner et al. 2012; Kopittke et al. 2018) and lowmolecular-weight plant compounds (Haddix et al. 2016) and thus possesses a low C:N ratio (Sollins et al. 2006), which generally promotes $\mathrm{N}$ mineralization via microbial N mining (Sollins et al. 1984; Whalen et al. 2000; Jilling et al. 2018).

Incubations of SOM fractions show higher rates of $\mathrm{N}$ mineralization from MAOM than POM (Bimüller et al. 2014), supporting recent evidence that MAOM is heterogeneous in chemistry and function, and some MAOM is relatively accessible (Mikutta and Kaiser 2011; Torn et al. 2013). Mineral-associated fractions can exhibit short-term $(<5$ years $)$ changes in $\mathrm{C}$ and $\mathrm{N}$ content (Heckman et al. 2013; von Haden et al. 2019; Jilling et al. 2020), indicating a fraction of this pool cycles on relatively rapid time scales. Soil capacity to accumulate MAOM has also been linked to aboveground productivity: Cates and Ruark (2017) observed a positive association between the non-aggregated silt and clay fraction and crop yield. Similarly, both POM and MAOM have been positively associated with select measures of $\mathrm{N}$ availability and crop performance (Wade et al. 2018; Jilling et al. 2020). Because MAOM includes both easily exchangeable and highly persistent fractions, minerals can retain organic compounds-building SOM-while also supplying bioavailable $\mathrm{N}$.

MAOM formation from POM can be fast: minerals quickly stabilize POM-derived $\mathrm{N}$, as demonstrated by the rapid transfer of ${ }^{15} \mathrm{~N}$-labelled residues into MAOM fractions (Kölbl et al. 2006; Bosshard et al. 
2008; Poirier et al. 2020; T.M. Bowles, unpublished data). $\mathrm{N}$ associated with minerals can be remobilized, in part because MAOM often accrues not as a continuous layer but rather as patches that vertically extend outward from mineral surfaces (Vogel et al. 2014) or bind only via weak bonds and may thus be more likely to exchange or interact with the soil solution (Kleber et al. 2007; Gao et al. 2020). Desorption potential of $\mathrm{ON}$ also differs between clay mineral types due to their variation in surface area and charge characteristics. Yet microbes are able to access some ON associated with minerals-even from iron and aluminum oxides that bind $\mathrm{ON}$ more strongly than most phyllosilicate clays (Kaiser and Zech 2000; Kleber et al. 2005; Mikutta et al. 2005).

In recent years, evidence has emerged that rhizosphere processes mobilize MAOM-N (Jilling et al. 2018; Fig. 2: N from MAOM in the rhizosphere). Root $\mathrm{C}$ inputs and the release of $\mathrm{H}^{+}$and $\mathrm{OH}^{-}$during cation or anion uptake cause dramatic, localized shifts in both $\mathrm{pH}$ and soil solution chemistry that alter organic matter sorption onto, or mobilization from, mineral surfaces (Avena and Koopal 1998; Rashad et al. 2010; Kleber et al. 2015; Singh et al. 2016). Strong ligands such as oxalate and citrate released by roots can mobilize MAOM-N by exchanging for organic compounds held in metal-organic complexes (Kleber et al. 2015) or by dissolving minerals such as iron and aluminum (hydr)oxides (Xyla et al. 1992; Vempati et al. 1995). Plant roots can secrete enzymes including extracellular proteases to break large $\mathrm{N}$ polymers into bioavailable N (Tornkvist et al. 2019). Plant rhizodeposits include large amounts of photosynthetically fixed carbon (e.g. Litton et al. 2007) and simple, low molecular weight exudates (Dennis et al. 2010) that influence mineral solubility (Hinsinger and Courchesne 2007; Calvaruso et al. 2014; Keiluweit et al. 2015).

In addition to these direct effects, rhizodeposition can indirectly undermine the stability of mineral-SOM associations (Keiluweit et al. 2015; Jilling et al. 2018). Root inputs can "prime" MAOM- N mobilization indirectly by stimulating microbial activity, which generates acidity and depletes oxygen. This can alter the redox state of metals, causing MAOM-N to be released (Fischer et al. 1989; Grybos et al. 2009; Husson 2013; Buettner et al. 2014). These root deposits can also stimulate microbes to produce extracellular enzymes, notably oxidases that are effective at destabilizing SOM (Sinsabaugh 2009; Phillips et al. 2011; Zhu et al. 2014; Partavian et al. 2015; Kieloaho et al. 2016; Wang et al. 2020b).

Microbial organic $\mathrm{N}$ turnover: uptake, assimilation, recycling, mineralization

The physiological traits of microbes shape how $\mathrm{N}$ flows through the microbial compartment (Fig. 1, blue box) by affecting extracellular depolymerization, cellular uptake, metabolic and biosynthetic allocation, and finally plant uptake or environmental losses in inorganic and organic forms. First, microbes acquire $\mathrm{ON}$ at rates that depend on the characteristics of (a) the extracellular enzymes that produce small peptides and $\mathrm{N}$ monomers from larger substrates, and (b) the membrane transport proteins that move the resulting bioavailable ON into microbial cells. These two classes of proteins can vary between microbes in functionally relevant characteristics including abundance, specificity, efficiency, inducibility, and the energetic costs required for microbes to build and operate them. If microbes take up peptides rather than monomers they can invest less in $\mathrm{ON}$ decomposition (Hobbie and Hobbie 2012) though this could also require more specialized and expensive transporters (Davis et al. 2005). Microbes can assimilate ON more efficiently if they have traits that confer stoichiometric or metabolic flexibility, for example by responding to molecule or element limitation by switching to alternative energy or biosynthesis pathways that use more favorable substrate molecules (Smith and Chapman 2010). Adaptive traits like luxury $\mathrm{N}$ consumption and storage can accrue $\mathrm{N}$ in cellular biomass (Frost et al. 2005), while competitive or cooperative traits can release $\mathrm{N}$ into the soil environment in compounds like antibiotics and the protein components of extracellular polymeric substances (Allison 2005; Ren et al. 2015; Estrela et al. 2019; Cai et al. 2019; GarciaGarcera and Rocha 2020). Microbes can lose N passively as concentration gradients drive reverse diffusion through permease sites (Krämer 1994; Button 1998) to an extent that likely varies between microbes with different $\mathrm{N}$ uptake systems. Physiological traits that confer stress resistance may limit microbial ON loss by reducing membrane disruptions.

SON recycling and MAOM-N accumulation will arise in part from the outcome of microbial N-allocation to biomass, excreted biomolecular products, and 
mineralized N. Initial evidence suggests that greater recycling of microbial $\mathrm{N}$ within the soil environment lessens inorganic $\mathrm{N}$ waste excretion by microbes (Zhang et al. 2019). Fast microbial growth provides more opportunities for recycling of microbial $\mathrm{N}$ within the soil as microbial lysates, necromass, and biomolecular products are re-incorporated into microbial biomass or sorbed to soil minerals. External factors that accelerate microbial biomass turnover and release microbial $\mathrm{N}$ into the soil environment include seasonal changes in temperature and moisture; predation by micro- and mesofauna and viruses; and the chemistry, amount, and variability of plant root inputs (Clarholm 1985; Singh et al. 1989; Lipson et al. 1999; Scheu 2002; Kuzyakov and Mason-Jones 2018; Emerson 2019). Greater microbial carbon use efficiency (CUE) accelerates the accumulation of N-rich microbial products and necromass in soil (Kallenbach et al. 2016, 2019) by increasing the amount of microbial biomass produced per unit of substrate (Manzoni et al. 2012; Geyer et al. 2019) and may itself be driven by microbial community composition (Kallenbach et al. 2019; Domeignoz-Horta et al. 2020). The soil environment can modify microbial $\mathrm{N}$ allocation. For example, the proportion of assimilated $\mathrm{ON}$ that microbes released as waste $\mathrm{NH}_{4}{ }^{+}$decreased in suboxic conditions but increased with temperature (Zhang et al. 2019), and was moderately greater under long-term warming and drought (Wild et al. 2018). Further elucidating how microbial physiology responds to environmental controls will be critical in predicting when $\mathrm{N}$ will be mineralized versus recycled within SON pools.

Microbial release of $\mathrm{N}$ waste also depends on the elemental imbalance between microbial biomass and substrate resources (Sterner and Elser 2002; Li et al. 2020b). Soil microbial biomass has a relatively fixed average biomass $\mathrm{C}: \mathrm{N}$ ratio of 8:1 (Cleveland and Liptzin 2007; Kallenbach and Grandy 2011); stoichiometric theory predicts microbes achieve this by offloading excess substrate $\mathrm{C}$ or $\mathrm{N}$ as $\mathrm{CO}_{2}$ or $\mathrm{NH}_{4}{ }^{+}$ waste (Mooshammer et al. 2014b). Meanwhile, microbial substrates in soil environments range from very $\mathrm{N}$-rich $(\mathrm{C}: \mathrm{N}$ ratio of e.g. $<5: 1)$ to $\mathrm{N}$-poor containing little $\mathrm{N}$ (e.g. $>100: 1$ ) or no $\mathrm{N}$ (e.g. cellulose; Sinsabaugh et al. 2016), leading to a wide range in the intensity of the stoichiometric imbalance between microbes and SOM resources. Across soil and litter samples, Mooshammer et al. (2014a) noted much greater release of inorganic $\mathrm{N}$ waste when resource $\mathrm{C}: \mathrm{N}$ was similar to microbial $\mathrm{C}: \mathrm{N}$, which decreased as the gap between resource and microbial C:N widened, approaching minimum release of inorganic $\mathrm{N}$ at a microbe-resource stoichiometric imbalance of about four-fold. These observations suggest that a higher proportion of $\mathrm{N}$ will be mineralized from MAOM than from POM substrates due to MAOM's lower average $\mathrm{C}: \mathrm{N}$ ratio.

\section{Applications and future directions}

Our model can be applied to consider the delivery of bioavailable $\mathrm{N}$ from POM and MAOM in fertilized agroecosystems and disturbed systems (main text) as well as across seasons and in response to changes in soil moisture (Online Appendix).

POM and MAOM in degrading and aggrading soils

In the terms of our conceptual model, a degrading soil is one in which MAOM-N desorption rates exceed MAOM-N sorption rates; consequently, mineral sorption potential increases, and the soil shifts left along the $\mathrm{x}$-axis in Fig. 2. MAOM depletion could occur due to increased desorption rates, for example from $\mathrm{N}$-mining by plants, microbes, and plant-microbe consortia, or due to decreased sorption rates due to decreasing POM inputs. Indeed, in many degrading soils including those undergoing desertification or conversion to intensive agriculture, POM reserves are expected to decline, leaving MAOM as the primary source of bioavailable $\mathrm{N}$ without resupply, further depleting MAOM-N in an accelerating process of soil degradation. As disturbance continues to empty the MAOM pool and the mineral sink strengthens, we expect MAOM-N to become increasingly inaccessible. Soils with low sorption potential often rely primarily on POM to supply bioavailable $\mathrm{N}$ and are vulnerable to degradation due to the speed at which POM decomposes, particularly when new POM inputs also decline.

Refilling POM pools by restoring productive aboveground plant communities-for example through reforestation, perennialization, or cover cropping-can regenerate the ability of soils with low sorption potential to supply bioavailable N. Over time, large and consistent POM inputs can also replenish the 
degraded MAOM pools of soils with high mineral sorption potential. However, building MAOM pools requires a large amount of $\mathrm{N}$ per $\mathrm{C}$ because of its low $\mathrm{C}: \mathrm{N}$ ratio (Cotrufo et al. 2019), perhaps in part because the nitrogenous moieties in $\mathrm{ON}$ are particularly reactive with mineral sorption sites (Omoike and Chorover 2006; Lambert 2008) and seem to play an important role in forming organo-mineral complexes (Kleber et al. 2007). Therefore, MAOM may accrue more quickly from materials that are highly processed by microbes, from low $\mathrm{C}: \mathrm{N}$ materials, and from higher $\mathrm{C}: \mathrm{N}$ materials that are deposited simultaneously with a source of inorganic and/or organic N. For example, recent studies observed that manure had a greater capacity to build MAOM than crop residue (Samson et al. 2020), and that inorganic N, manure, and soybean additions each increased microbial conversion of maize residues to MAOM (Gillespie et al. 2014). Inputs that improve plant and microbial uptake of ON monomers (Ma et al. 2018) could increase recycling and retention of $\mathrm{ON}$ within soil, and particularly MAOM, pools. The ability to regenerate MAOM will also depend on whether soil conditions support the conversion of plant litter or exogenous organic inputs to MAOM, for example whether new $\mathrm{ON}$ inputs are in physical contact with minerals or accessible to microbial enzymes.

Accounting for MAOM-N in agroecosystem nutrient management

In agroecosystems, global fertilizer nitrogen use efficiency (NUE) remains stubbornly low at around $40 \%$, and must nearly double by 2050 to meet predicted food and environmental demands (Zhang et al. 2015). The modest success of technological solutions focused on fertilizer management (Xia et al. 2017; Norton and Ouyang 2019) reveals the shortcomings of a narrow focus on managing inorganic $\mathrm{N}$. Our model adds to calls for active management of SON (Gardner and Drinkwater 2009; Lin et al. 2016; Yan et al. 2020) and suggests that future agronomic research should seek to develop ways to enhance $\mathrm{N}$ supply from POM and MAOM when plant demand is high, but equally, to rebuild those SON pools during non-growing or fallow seasons.

Sites will require management practices tailored to their specific mineralogical properties and POM and MAOM concentrations. Sites with high mineral sorption capacity but low POM (Fig. 2, POM N supply $<<$ Mineral sorption potential) will supply little bioavailable $\mathrm{N}$ to crops, but have great potential to provide MAOM-N if management can increase POM inputs and their conversion to MAOM. Sites where POM-N supply and mineral sorption potential are balanced will need practices aimed toward maintenance of the POM and MAOM pools. Soils with very low mineral sorption potential or very high POM-N supply are prone to sizeable $\mathrm{N}$ losses (Fig. 2, POM N supply $>>$ Mineral sorption potential), and will benefit most from strategies that can absorb excess bioavailable $\mathrm{N}$ by increasing soil charge potential or metal cation concentrations to enhance MAOM-N storage, and by enlarging microbial biomass pools.

We expect inorganic $\mathrm{N}$ applications will substantially alter MAOM-N mobilization (Fig. 3, right) by suppressing the biological mechanisms that mobilize MAOM. Inorganic $\mathrm{N}$ can decrease plant-microbe mobilization of MAOM in the rhizosphere by selecting for microbes that are poorer decomposers or that are less responsive to root inputs; by shifting microbial communities to have fewer fungi; or by lowering overall microbial biomass (Treseder 2008; Fierer et al. 2012; Morrison et al. 2018; Jia et al. 2020). N fertilizer reduces mycorrhizal fungi that extend root surface area (Phillips et al. 2012; Morrison et al. 2016); N fertilizer can also accelerate the activity of hydrolytic enzymes such as beta-1,4-glucosidase, while reducing the activity of oxidative enzymes that mobilize MAOM (Grandy et al. 2008; Jilling et al. 2018; Chen et al. 2020). The acidifying effect of nitrification has also been theorized to reduce MAOM pools (Averill and Waring 2018). Thus, our framework is in line with Drinkwater and Snapp's (2007) argument that it is critical to recouple $\mathrm{C}$ and $\mathrm{N}$ cycles in agroecosystems to maximize yields while minimizing economic and environmental costs of $\mathrm{N}$ excess. For example, it suggests that MAOM pools can be best enriched by organic fertilizers like animal manure, crop residues, or compost (Leinweber and Reuter 1992; Chen et al. 2019; Huang et al. 2019; Xu et al. 2020), and that green manures and cover crops can convert inorganic $\mathrm{N}$ into POM inputs that both supply bioavailable $\mathrm{N}$ and build MAOM.

In addition to ongoing agronomic research that seeks to minimize inorganic $\mathrm{N}$ inputs, our model encourages development of strategies to engage the plant-microbe-soil interactions that accelerate $\mathrm{N}$ 
provisioning when and where $\mathrm{N}$ demand is high, such as during rapid vegetative growth phases and in the rhizosphere. For instance, crop breeding can select for plants with greater or better timed exudation of organic acids and root-secreted proteases; increased ability to interact with soil microbes like mycorrhizal fungi and to induce rhizosphere microbes to mine $\mathrm{N}$ from MAOM; more active amino acid importer proteins and a greater capacity to alter root growth phenotypes in response to changes in soil amino acid concentrations; and increased plant use of soil peptides (Forsum et al. 2008; Moe 2013; Moreau et al. 2019; Tornkvist et al. 2019; Preece and Peñuelas 2020). Agroecologists can also seek to develop management regimes that select for soil microbial communities that respond more to plant inputs, and are less influenced by soil inorganic $\mathrm{N}$ concentrations.

For managed ecosystems, we suggest seeking strategies that prioritize building MAOM pools and that re-conceptualize POM pools as a more secondary concern whose main import is to feed the microbes that generate MAOM. Soil management regimes should also select for microbes that can efficiently convert POM-N - and even excess organic and inorganic fertilizer $\mathrm{N}$-into microbial products that build MAOM-N. At the same time, these ideal soil microbes should readily depolymerize $\mathrm{ON}$ substrates and mobilize ON from minerals to generate bioavailable N. We posit that these microbial communities should be highly active to further increase the turnover and exchange of MAOM-N. A better understanding of soil microbial physiology related to ON cycling can ensure that the balance between these microbial effects will supply N but not deplete MAOM (Janzen 2006). Such developments in agronomic tools will lead to more tightly coupled plant-soil $\mathrm{N}$ cycling in which bioavailable $\mathrm{N}$ supply better coincides with plant $\mathrm{N}$ demand (Bowles et al. 2015).

Future directions

Our conceptual model of bioavailable $\mathrm{N}$ suggests that we need to address important knowledge gaps and increase research effort in several areas. Very little is known about the controls on gross protein depolymerization, and even less is known about how microbial taxa differ in their contributions to these controls. Insights in this area will also improve our understanding of bioavailable $\mathrm{N}$ dynamics in organic soils, such as histosols, which fall outside the scope of our model. Upstream of depolymerization, soil biota including soil meso- and microfauna physically fragment litter into POM and deposit N-rich feces (Wickings and Grandy 2011). How these animals influence MAOM formation and turnover remains to be determined (David 2014). Leachate from fresh litter is a direct and potentially large source of bioavailable $\mathrm{N}$ (Rinkes et al. 2014), and it may differ in its chemistry from compounds originating in POM or microbial products in ways that influence its associations with minerals. Insoluble macromolecules of plant and microbial origin also associate with minerals (Lehmann and Kleber 2015) and, because they are subject to both desorption and depolymerization, likely have multiple controls. Aggregation and other types of physical occlusion (e.g. low pore connectivity or soil moisture) may further modify the dynamics of MAOM turnover and ON bioavailability. Finally, plants are both sinks for bioavailable $\mathrm{N}$ and sources of $\mathrm{ON}$ in the form of litter deposits, and differences in plant-microbe-soil interactions could cause plants to vary in how they influence bioavailable $\mathrm{N}$ cycling across environments, especially in ecosystems where plants also assimilate especially large amounts of organic N such as the Arctic (Sorensen et al. 2008).

Our model recognizes the importance of microbial physiology in partitioning $\mathrm{N}$ between SOM and inorganic pools. There is much to learn about how the flow of ON through the microbial pool is shaped by microbial identity and genomic potential, community structure and interactions, and constraints of the soil environment. Do different microbes or consortia vary in their expression of $\mathrm{ON}$ degrading and uptake transport proteins, in their growth rates and efficiencies, or in their metabolic flexibility and how they allocate $\mathrm{N}$ from organic sources? How does recycling of bioavailable $\mathrm{N}$ between MAOM and microbes alter its chemistry and future bioavailability? How do microbes alter their use of ON in response to stress, particularly the types of stress they will increasingly face in a changing climate? Use of appropriate measures of microbial growth efficiency (Frey et al. 2013; Geyer et al. 2016) and the increasing power of functional omics and meta-omics technologies (Sergaki et al. 2018; Pinu et al. 2019; Nannipieri et al. 2020; Ichihashi et al. 2020; Tang and Aristilde 2020; Naylor et al. 2020) are advancing this exciting new theme in soil biogeochemical research. 
Given that soil mineral composition likely drives at least part of the site specificity so often found in studies of SON, we need to clarify the ways in which minerals affect bioavailable $\mathrm{N}$ cycling. There remain uncertainties around the most basic interactions between various bioavailable $\mathrm{N}$ species and different minerals, the strength of these interactions, and their vulnerability to disruption (Schulten and Schnitzer 1997; Kleber et al. 2015). We will require more detailed characterization of the ways different $\mathrm{ON}$ polymers and monomers interact chemically with one another, with inorganic $\mathrm{N}$ and other solutes including metallic ions, and with enzymes and redox processes. Researchers have gained new insights into the 3-D architecture of organo-mineral interactions (Mueller et al. 2013) and how organic compounds fractionate between soil mineral pools (Heckman et al. 2013); they have learned that some minerals preferentially sorb dissolved ON over compounds lacking N. How these insights relate to bioavailable $\mathrm{N}$ deserves more detailed inquiry. At the same time, we recognize that "MAOM" originated as an operational term for organic matter attached to dense and/or small (typically $<53 \mu \mathrm{m}$ ) particles (Cambardella and Elliott 1992; Jastrow 1996), but that this fraction can incidentally include very small POM fragments and insoluble ON (Lavallee et al. 2020). The emerging conceptual understanding of MAOM as a pool of potentially soluble $\mathrm{ON}$ of diverse chemical makeup calls for more sophisticated characterization of this soil fraction.

\section{Conclusion}

We present a new framework of bioavailable $\mathrm{N}$ cycling based on the interactions between organic $\mathrm{N}$ depolymerization, mineral sorption-desorption dynamics, and the actions of plants and microbes. New research, enabled by methodological advances of the last decade, has revealed depolymerization to be a dynamic process that drives substantial fluxes of bioavailable $\mathrm{N}$ from POM; this organic $\mathrm{N}$ subsequently associates with soil minerals to form MAOM, a large and heterogeneous pool of SOM enriched in nutrients that roots and microbes can actively mine. Our framework suggests that the flow of bioavailable $\mathrm{N}$ from MAOM is based on the relative balance between POM-N inputs and the soil's mineral sorption potential, further shaped by plant-microbe interactions and environmental conditions. Microbial physiological traits substantially impact the entire bioavailable $\mathrm{N}$ cycle. By accounting for MAOM-N dynamics, we can develop agricultural management strategies that better minimize $\mathrm{N}$ pollution while reaching crop yield goals. As the SON paradigm is reshaped-the way SOC paradigm has been reshaped over the last two decades-new avenues will open to understanding the cycling of bioavailable $\mathrm{N}$.

Acknowledgement Figure 3 was illustrated by Elena Hartley Science Illustration (elabarts.com).

Funding R.W.B. is supported by a Postdoctoral Fellowship from the Natural Science and Engineering Research Council of Canada. M.M., T.B., and A.S.G received funds from the USDA NIFA Agriculture and Food Research Initiative (Award No. 2017-67013-26254). A.S.G received funds from the USDA NIFA National Research Initiative (Award No. 2015-3561522747). M.K. was supported by the US Department of Energy, Office of Biological and Environmental Research, Subsurface Biogeochemical Research program (Award No. DESC0019477). A.B.D received support from the NSF Graduate Research Fellowship Program (Award No. DGE1450271) and the USDA NIFA Agriculture and Food Research Initiative (Award No. 2011-67003-30343). A.J. received funds from USDA NIFA Hatch (1023682). Partial funding was provided by the New Hampshire Agricultural Experiment Station. This is Scientific Contribution Number 2893.

\section{Declarations}

Conflict of interest The authors have no conflicts of interest to declare that are relevant to the content of this article.

Open Access This article is licensed under a Creative Commons Attribution 4.0 International License, which permits use, sharing, adaptation, distribution and reproduction in any medium or format, as long as you give appropriate credit to the original author(s) and the source, provide a link to the Creative Commons licence, and indicate if changes were made. The images or other third party material in this article are included in the article's Creative Commons licence, unless indicated otherwise in a credit line to the material. If material is not included in the article's Creative Commons licence and your intended use is not permitted by statutory regulation or exceeds the permitted use, you will need to obtain permission directly from the copyright holder. To view a copy of this licence, visit http://creativecommons.org/licenses/by/4.0/.

\section{References}

Abelenda MS, Buurman P, Arbestain MC et al (2011) Comparing $\mathrm{NaOH}$-extractable organic matter of acid forest soils 
that differ in their pedogenic trends: a pyrolysis-GC/MS study. Eur J Soil Sci 62:834-848. https://doi.org/10.1111/j. 1365-2389.2011.01404.x

Abramoff R, Xu X, Hartman M et al (2018) The Millennial model: in search of measurable pools and transformations for modeling soil carbon in the new century. Biogeochemistry 137:51-71. https://doi.org/10.1007/s10533-0170409-7

Allison SD (2005) Cheaters, diffusion and nutrients constrain decomposition by microbial enzymes in spatially structured environments. Ecol Lett 8:626-635. https://doi.org/ 10.1111/j.1461-0248.2005.00756.x

Avena MJ, Koopal LK (1998) Desorption of humic acids from an iron oxide surface. Environ Sci Technol 32:2572-2577. https://doi.org/10.1021/es980112e

Averill C, Waring B (2018) Nitrogen limitation of decomposition and decay: how can it occur? Glob Change Biol 24:1417-1427. https://doi.org/10.1111/gcb.13980

Baldock JA, Skjemstad JO (2000) Role of the soil matrix and minerals in protecting natural organic materials against biological attack. Org Geochem 31:697-710. https://doi. org/10.1016/S0146-6380(00)00049-8

Bimüller C, Mueller CW, von Lützow M et al (2014) Decoupled carbon and nitrogen mineralization in soil particle size fractions of a forest topsoil. Soil Biol Biochem 78:263-273. https://doi.org/10.1016/j.soilbio.2014.08.001

Blagodatsky S, Blagodatskaya E, Yuyukina T, Kuzyakov Y (2010) Model of apparent and real priming effects: linking microbial activity with soil organic matter decomposition. Soil Biol Biochem 42:1275-1283. https://doi.org/10.1016/ j.soilbio.2010.04.005

Bosshard C, Frossard E, Dubois D et al (2008) Incorporation of nitrogen-15-labeled amendments into physically separated soil organic matter fractions. Soil Sci Soc Am J 72:949-959. https://doi.org/10.2136/sssaj2006.0376

Bowles TM, Hollander AD, Steenwerth K, Jackson LE (2015) Tightly-coupled plant-soil nitrogen cycling: comparison of organic farms across an agricultural landscape. PLoS ONE 10:e131888. https://doi.org/10.1371/journal.pone. 0131888

Bowles TM, Atallah SS, Campbell EE et al (2018) Addressing agricultural nitrogen losses in a changing climate. Nat Sustain 1:399-408. https://doi.org/10.1038/s41893-0180106-0

Buettner SW, Kramer MG, Chadwick OA, Thompson A (2014) Mobilization of colloidal carbon during iron reduction in basaltic soils. Geoderma 221-222:139-145. https://doi. org/10.1016/j.geoderma.2014.01.012

Button DK (1998) Nutrient uptake by microorganisms according to kinetic parameters from theory as related to cytoarchitecture. Microbiol Mol Biol Rev 62:636-645

Buurman P, Roscoe R (2011) Different chemical composition of free light, occluded light and extractable SOM fractions in soils of Cerrado and tilled and untilled fields, Minas Gerais, Brazil: a pyrolysis-GC/MS study. Eur J Soil Sci 62:253-266. https://doi.org/10.1111/j.1365-2389.2010. 01327.x

Cai P, Sun X, Wu Y et al (2019) Soil biofilms: microbial interactions, challenges, and advanced techniques for exsitu characterization. Soil Ecol Lett 1:85-93. https://doi. org/10.1007/s42832-019-0017-7
Calvaruso C, Collignon C, Kies A, Turpault M-P (2014) Seasonal evolution of the rhizosphere effect on major and trace elements in soil solutions of norway spruce (Picea abies Karst) and beech (Fagus sylvatica) in an acidic forest soil. Open J Soil Sci 4:323-336. https://doi.org/10.4236/ojss. 2014.49034

Cambardella CA, Elliott ET (1992) Particulate soil organicmatter changes across a grassland cultivation sequence. Soil Sci Soc Am J 56:777-783. https://doi.org/10.2136/ sssaj 1992.03615995005600030017x

Čapek P, Manzoni S, Kaštovská E et al (2018) A plant-microbe interaction framework explaining nutrient effects on primary production. Nat Ecol Evol 2:1588-1596. https://doi. org/10.1038/s41559-018-0662-8

Cates AM, Ruark MD (2017) Soil aggregate and particulate C and $\mathrm{N}$ under corn rotations: responses to management and correlations with yield. Plant Soil 415:521-533. https://doi. org/10.1007/s11104-016-3121-9

Chen X, Wu J, Opoku-Kwanowaa Y (2019) Effects of organic wastes on soil organic carbon and surface charge properties in primary saline-alkali soil. Sustainability 11:7088. https://doi.org/10.3390/su11247088

Chen W, Zhou H, Wu Y et al (2020) Direct and indirect influences of long-term fertilization on microbial carbon and nitrogen cycles in an alpine grassland. Soil Biol Biochem 149:107922. https://doi.org/10.1016/j.soilbio.2020. 107922

Cheng W, Coleman DC (1990) Effect of living roots on soil organic matter decomposition. Soil Biol Biochem 22:781-787. 0717(90)90157-U

Cissé G, van Oort F, Chenu C et al (2020) Is the operationally defined fraction of soil organic matter, "GRSP" (glomalinrelated soil protein), stable in soils? Evidence from trends in long-term bare fallow soil. Eur J Soil Sci. https://doi.org/ 10.1111/ejss.12974

Clarholm M (1985) Interactions of bacteria, protozoa and plants leading to mineralization of soil nitrogen. Soil Biol Biochem 17:181-187. https://doi.org/10.1016/00380717(85)90113-0

Cleveland CC, Liptzin D (2007) C : N : P stoichiometry in soil: is there a "Redfield ratio" for the microbial biomass? Biogeochemistry 85:235-252

Clivot H, Mary B, Valé M et al (2017) Quantifying in situ and modeling net nitrogen mineralization from soil organic matter in arable cropping systems. Soil Biol Biochem 111:44-59. https://doi.org/10.1016/j.soilbio.2017.03.010

Cotrufo MF, Ranalli MG, Haddix ML et al (2019) Soil carbon storage informed by particulate and mineral-associated organic matter. Nat Geosci 12:989-994. https://doi.org/10. 1038/s41561-019-0484-6

Curtin D, McCallum FM (2004) Biological and chemical assays to estimate nitrogen supplying power of soils with contrasting management histories. Soil Res 42:737-746. https://doi.org/10.1071/SR03158

Curtin D, Beare MH, Lehto K et al (2017) Rapid assays to predict nitrogen mineralization capacity of agricultural soils. Soil Sci Soc Am J 81:979-991. https://doi.org/10. 2136/sssaj2016.08.0265

Dai Z, Yu M, Chen H et al (2020) Elevated temperature shifts soil $\mathrm{N}$ cycling from microbial immobilization to enhanced 
mineralization, nitrification and denitrification across global terrestrial ecosystems. Glob Change Biol 26:5267-5276. https://doi.org/10.1111/gcb.15211

Darrouzet-Nardi A, Weintraub MN (2014) Evidence for spatially inaccessible labile $\mathrm{N}$ from a comparison of soil core extractions and soil pore water lysimetry. Soil Biol Biochem 73:22-32. https://doi.org/10.1016/j.soilbio.2014.02. 010

David JF (2014) The role of litter-feeding macroarthropods in decomposition processes: a reappraisal of common views. Soil Biol Biochem 76:109-118. https://doi.org/10.1016/j. soilbio.2014.05.009

Davis MA, Askin MC, Hynes MJ (2005) Amino Acid catabolism by an area-regulated gene encoding an 1-amino acid oxidase with broad substrate specificity in Aspergillus nidulans. Appl Environ Microbiol 71:3551. https://doi.org/ 10.1128/AEM.71.7.3551-3555.2005

Denef K, Galdo ID, Venturi A, Cotrufo MF (2013) Assessment of soil $\mathrm{C}$ and $\mathrm{N}$ stocks and fractions across 11 European Soils under Varying Land Uses. Open J Soil Sci 3:297-313. https://doi.org/10.4236/ojss.2013.37035

Dennis PG, Miller AJ, Hirsch PR (2010) Are root exudates more important than other sources of rhizodeposits in structuring rhizosphere bacterial communities? FEMS Microbiol Ecol 72:313-327. https://doi.org/10.1111/j.1574-6941.2010. 00860.x

Dessureault-Rompré J, Zebarth BJ, Burton DL, Georgallas A (2014) Predicting soil nitrogen supply from soil properties. Can J Soil Sci 95:63-75. https://doi.org/10.4141/cjss2014-057

Di Lonardo DP, De Boer W, Klein Gunnewiek PJA et al (2017) Priming of soil organic matter: chemical structure of added compounds is more important than the energy content. Soil Biol Biochem 108:41-54. https://doi.org/10.1016/j.soilbio. 2017.01.017

Dijkstra FA, Cheng W (2007) Interactions between soil and tree roots accelerate long-term soil carbon decomposition. Ecol Lett 10:1046-1053. https://doi.org/10.1111/j.1461-0248. 2007.01095.x

Dippold M, Biryukov M, Kuzyakov Y (2014) Sorption affects amino acid pathways in soil: implications from positionspecific labeling of alanine. Soil Biol Biochem 72:180-192. https://doi.org/10.1016/j.soilbio.2014.01.015

Domeignoz-Horta LA, Pold G, Liu X-JA et al (2020) Microbial diversity drives carbon use efficiency in a model soil. Nat Commun 11:3684. https://doi.org/10.1038/s41467-02017502-Z

Drinkwater LE, Snapp SS (2007) Nutrients in agroecosystems: rethinking the management paradigm. Adv Agron 92:163

Emerson JB (2019) Soil viruses: a new hope. mSystems. https:// doi.org/10.1128/mSystems.00120-19

Estrela S, Libby E, Van Cleve J et al (2019) Environmentally mediated social dilemmas. Trends Ecol Evol 34:6-18. https://doi.org/10.1016/j.tree.2018.10.004

Fabrizzi KP, Morón A, García FO (2003) Soil carbon and nitrogen organic fractions in degraded vs. non-degraded mollisols in Argentina. Soil Sci Soc Am J 67:1831-1841. https://doi.org/10.2136/sssaj2003.1831

Farrell M, Hill PW, Farrar J et al (2013) Oligopeptides represent a preferred source of organic $\mathrm{N}$ uptake: a global phenomenon? Ecosystems 16:133-145. https://doi.org/10. 1007/s10021-012-9601-8

Farrell M, Prendergast-Miller M, Jones DL et al (2014) Soil microbial organic nitrogen uptake is regulated by carbon availability. Soil Biol Biochem 77:261-267. https://doi. org/10.1016/j.soilbio.2014.07.003

Fierer N, Lauber CL, Ramirez KS et al (2012) Comparative metagenomic, phylogenetic and physiological analyses of soil microbial communities across nitrogen gradients. ISME J 6:1007-1017. https://doi.org/10.1038/ismej.2011. 159

Fischer WR, Flessa H, Schaller G (1989) pH values and redox potentials in microsites of the rhizosphere. Z Für Pflanzenernähr Bodenkd 152:191-195. https://doi.org/10. 1002/jpln. 19891520209

Fornara DA, Steinbeiss S, McNAMARA NP et al (2011) Increases in soil organic carbon sequestration can reduce the global warming potential of long-term liming to permanent grassland. Glob Change Biol 17:1925-1934. https://doi.org/10.1111/j.1365-2486.2010.02328.x

Forsum O, Svennerstam H, Ganeteg U, Naesholm T (2008) Capacities and constraints of amino acid utilization in Arabidopsis. New Phytol 179:1058-1069. https://doi.org/ 10.1111/j.1469-8137.2008.02546.x

Fox RH, Piekielek WP (1984) Relationships among anaerobically mineralized nitrogen, chemical indexes, and nitrogen availability to corn. Soil Sci Soc Am J 48:1087-1090. https://doi.org/10.2136/sssaj1984. $03615995004800050027 \mathrm{x}$

Frey SD (2019) Mycorrhizal fungi as mediators of soil organic matter dynamics. Annu Rev Ecol Evol Syst 50:237-259. https://doi.org/10.1146/annurev-ecolsys-110617-062331

Frey SD, Lee J, Melillo JM, Six J (2013) The temperature response of soil microbial efficiency and its feedback to climate. Nat Clim Change 3:395-398. https://doi.org/10. 1038/nclimate1796

Frost PC, Evans-White MA, Finkel ZV et al (2005) Are you what you eat? Physiological constraints on organismal stoichiometry in an elementally imbalanced world. Oikos 109:18-28. https://doi.org/10.1111/j.0030-1299.2005. 14049.x

Gao J, Mikutta R, Jansen B et al (2020) The multilayer model of soil mineral-organic interfaces-a review. J Plant Nutr Soil Sci 183:27-41. https://doi.org/10.1002/jpln.201900530

Garcia-Garcera M, Rocha EPC (2020) Community diversity and habitat structure shape the repertoire of extracellular proteins in bacteria. Nat Commun 11:758. https://doi.org/10. 1038/s41467-020-14572-x

Gardner JB, Drinkwater LE (2009) The fate of nitrogen in grain cropping systems: a meta-analysis of $15 \mathrm{~N}$ field experiments. Ecol Appl 19:2167-2184. https://doi.org/10.1890/ 08-1122.1

Geisseler D, Horwath WR (2014) Investigating amino acid utilization by soil microorganisms using compound specific stable isotope analysis. Soil Biol Biochem 74:100-105. https://doi.org/10.1016/j.soilbio.2014.02.024

Geyer KM, Kyker-Snowman E, Grandy AS, Frey SD (2016) Microbial carbon use efficiency: accounting for population, community, and ecosystem-scale controls over the fate of metabolized organic matter. Biogeochemistry 127:173-188. https://doi.org/10.1007/s10533-016-0191-y 
Geyer KM, Dijkstra P, Sinsabaugh R, Frey SD (2019) Clarifying the interpretation of carbon use efficiency in soil through methods comparison. Soil Biol Biochem 128:79-88. https://doi.org/10.1016/j.soilbio.2018.09.036

Gillespie AW, Diochon A, Ma BL et al (2014) Nitrogen input quality changes the biochemical composition of soil organic matter stabilized in the fine fraction: a long-term study. Biogeochemistry 117:337-350. https://doi.org/10. 1007/s10533-013-9871-z

Gleixner G, Czimczik CJ, Kramer C et al (2001) Plant compounds and their turnover and stabilization as soil organic matter. Global biogeochemical cycles in the climate system. Academic Press, Cambridge, pp 201-215

Gleixner G, Poirier N, Bol R, Balesdent J (2002) Molecular dynamics of organic matter in a cultivated soil. Org Geochem 33:357-366

Grandy AS, Robertson GP (2007) Land-use intensity effects on soil organic carbon accumulation rates and mechanisms. Ecosystems 10:59-74. https://doi.org/10.1007/s10021006-9010-y

Grandy AS, Neff JC (2008) Molecular C dynamics downstream: the biochemical decomposition sequence and its impact on soil organic matter structure and function. Sci Total Environ 404:297-307. https://doi.org/10.1016/j.scitotenv. 2007.11.013

Grandy A, Sinsabaugh R, Neff J et al (2008) Nitrogen deposition effects on soil organic matter chemistry are linked to variation in enzymes, ecosystems and size fractions. Biogeochemistry 91:37-49. https://doi.org/10.1007/s10533008-9257-9

Grandy AS, Strickland MS, Lauber CL et al (2009) The influence of microbial communities, management, and soil texture on soil organic matter chemistry. Geoderma 150:278-286. https://doi.org/10.1016/j.geoderma.2009.02. 007

Grybos M, Davranche M, Gruau G et al (2009) Increasing pH drives organic matter solubilization from wetland soils under reducing conditions. Geoderma 154:13-19. https:// doi.org/10.1016/j.geoderma.2009.09.001

Haddix ML, Paul EA, Cotrufo MF (2016) Dual, differential isotope labeling shows the preferential movement of labile plant constituents into mineral-bonded soil organic matter. Glob Change Biol 22:2301-2312. https://doi.org/10.1111/ gcb. 13237

Harmsen GW, Van Schreven DA (1955) Mineralization of organic nitrogen in soil. Adv Agron 7:299-398

Heckman K, Grandy AS, Gao X et al (2013) Sorptive fractionation of organic matter and formation of organo-hydroxy-aluminum complexes during litter biodegradation in the presence of gibbsite. Geochim Cosmochim Acta 121:667-683. https://doi.org/10.1016/j.gca.2013.07.043

Hill PW, Farrell M, Jones DL (2012) Bigger may be better in soil $\mathrm{N}$ cycling: does rapid acquisition of small 1-peptides by soil microbes dominate fluxes of protein-derived $\mathrm{N}$ in soil? Soil Biol Biochem 48:106-112. https://doi.org/10.1016/j. soilbio.2012.01.023

Hinsinger P, Courchesne F (2007) Biogeochemistry of metals and metalloids at the soil-root interface. In: Vlante A, Huang PM (eds) Biophysico-chemical processes of heavy metals and metalloids in soil environments. Wiley, New York, pp 265-311
Hobbie JE, Hobbie EA (2012) Amino acid cycling in plankton and soil microbes studied with radioisotopes: measured amino acids in soil do not reflect bioavailability. Biogeochemistry 107:339-360. https://doi.org/10.1007/s10533010-9556-9

Houlton BZ, Almaraz M, Aneja V et al (2019) A World of cobenefits: solving the global nitrogen challenge. Earths Future 7:865-872. https://doi.org/10.1029/2019EF001222

Hu Y, Zheng Q, Zhang S et al (2018) Significant release and microbial utilization of amino sugars and d-amino acid enantiomers from microbial cell wall decomposition in soils. Soil Biol Biochem 123:115-125. https://doi.org/10. 1016/j.soilbio.2018.04.024

Hu Y, Zheng Q, Noll L et al (2020) Direct measurement of the in situ decomposition of microbial-derived soil organic matter. Soil Biol Biochem 141:107660. https://doi.org/10. 1016/j.soilbio.2019.107660

Huang X, Jia Z, Guo J et al (2019) Ten-year long-term organic fertilization enhances carbon sequestration and calciummediated stabilization of aggregate-associated organic carbon in a reclaimed Cambisol. Geoderma 355:113880. https://doi.org/10.1016/j.geoderma.2019.113880

Husson O (2013) Redox potential (Eh) and $\mathrm{pH}$ as drivers of soil/plant/microorganism systems: a transdisciplinary overview pointing to integrative opportunities for agronomy. Plant Soil 362:389-417. https://doi.org/10.1007/ s11104-012-1429-7

Ichihashi Y, Date Y, Shino A et al (2020) Multi-omics analysis on an agroecosystem reveals the significant role of organic nitrogen to increase agricultural crop yield. Proc Natl Acad Sci USA 117:14552-14560. https://doi.org/10.1073/pnas. 1917259117

Janzen HH (2006) The soil carbon dilemma: shall we hoard it or use it? Soil Biol Biochem 38:419-424. https://doi.org/10. 1016/j.soilbio.2005.10.008

Jastrow JD (1996) Soil aggregate formation and the accrual of particulate and mineral-associated organic matter. Soil Biol Biochem 28:665-676. https://doi.org/10.1016/00380717(95)00159-X

Jia X, Zhong Y, Liu J et al (2020) Effects of nitrogen enrichment on soil microbial characteristics: from biomass to enzyme activities. Geoderma 366:114256. https://doi.org/10.1016/ j.geoderma.2020.114256

Jilling A, Keiluweit M, Contosta AR et al (2018) Minerals in the rhizosphere: overlooked mediators of soil nitrogen availability to plants and microbes. Biogeochemistry 139:103-122. https://doi.org/10.1007/s10533-018-0459-5

Jilling A, Kane D, Williams A et al (2020) Rapid and distinct responses of particulate and mineral-associated organic nitrogen to conservation tillage and cover crops. Geoderma 359:114001. https://doi.org/10.1016/j.geoderma.2019. 114001

Jones DL, Kielland K, Sinclair FL et al (2009) Soil organic nitrogen mineralization across a global latitudinal gradient. Global Biogeochem Cycles 23:1-5. https://doi.org/10. 1029/2008GB003250

Kaiser K, Zech W (2000) Dissolved organic matter sorption by mineral constituents of subsoil clay fractions. J Plant Nutr Soil Sci 163:531-535. https://doi.org/10.1002/15222624(200010)163:5\%3c531::AID-JPLN531\%3e3.0. $\mathrm{CO} ; 2-\mathrm{N}$ 
Kaiser C, Franklin O, Dieckmann U, Richter A (2014) Microbial community dynamics alleviate stoichiometric constraints during litter decay. Ecol Lett 17:680-690. https://doi.org/ 10.1111/ele.12269

Kallenbach C, Grandy AS (2011) Controls over soil microbial biomass responses to carbon amendments in agricultural systems: a meta-analysis. Agric Ecosyst Environ 144:241-252. https://doi.org/10.1016/j.agee.2011.08.020

Kallenbach CM, Frey SD, Grandy AS (2016) Direct evidence for microbial-derived soil organic matter formation and its ecophysiological controls. Nat Commun 7:13630. https:// doi.org/10.1038/ncomms 13630

Kallenbach CM, Wallenstein MD, Schipanksi ME, Grandy AS (2019) Managing agroecosystems for soil microbial carbon use efficiency: ecological unknowns, potential outcomes, and a path forward. Front Microbiol. https://doi.org/10. 3389/fmicb.2019.01146

Keiluweit M, Bougoure JJ, Nico PS et al (2015) Mineral protection of soil carbon counteracted by root exudates. Nat Clim Change 5:588-595. https://doi.org/10.1038/ nclimate 2580

Kielland K, McFarland JW, Ruess RW, Olson K (2007) Rapid cycling of organic nitrogen in taiga forest ecosystems. Ecosystems 10:360-368

Kieloaho A-J, Pihlatie M, Dominguez Carrasco M et al (2016) Stimulation of soil organic nitrogen pool: the effect of plant and soil organic matter degrading enzymes. Soil Biol Biochem 96:97-106. https://doi.org/10.1016/j.soilbio. 2016.01.013

Kleber M, Mikutta R, Torn MS, Jahn R (2005) Poorly crystalline mineral phases protect organic matter in acid subsoil horizons. Eur J Soil Sci 56:717-725. https://doi.org/10. 1111/j.1365-2389.2005.00706.x

Kleber M, Sollins P, Sutton R (2007) A conceptual model of organo-mineral interactions in soils: self-assembly of organic molecular fragments into zonal structures on mineral surfaces. Biogeochemistry 85:9-24. https://doi. org/10.1007/s10533-007-9103-5

Kleber M, Nico PS, Plante A et al (2011) Old and stable soil organic matter is not necessarily chemically recalcitrant: implications for modeling concepts and temperature sensitivity. Glob Change Biol 17:1097-1107

Kleber M, Eusterhues K, Keiluweit M et al (2015) Mineralorganic associations: formation, properties, and relevance in soil environments. In: Sparks DL (ed) Advances in agronomy, vol 130. Elsevier, Amsterdam, pp 1-140

Kölbl A, von Lützow M, Kögel-Knabner I (2006) Decomposition and distribution of $15 \mathrm{~N}$ labelled mustard litter (Sinapis alba) in physical soil fractions of a cropland with high- and low-yield field areas. Soil Biol Biochem 38:3292-3302. https://doi.org/10.1016/j.soilbio.2006.04.010

Kopittke PM, Hernandez-Soriano MC, Dalal RC et al (2018) Nitrogen-rich microbial products provide new organomineral associations for the stabilization of soil organic matter. Glob Change Biol 24:1762-1770. https://doi.org/ 10.1111/gcb.14009

Krämer R (1994) Secretion of amino acids by bacteria: physiology and mechanism. FEMS Microbiol Rev 13:75-93. https://doi.org/10.1111/j.1574-6976.1994.tb00036.x
Krull ES, Skjemstad JO, Baldock JA (2004) Functions of soil organic matter on soil properties: a literature review. CSIRO Land and Water, Clayton

Kuzyakov Y, Mason-Jones K (2018) Viruses in soil: nano-scale undead drivers of microbial life, biogeochemical turnover and ecosystem functions. Soil Biol Biochem 127:305-317. https://doi.org/10.1016/j.soilbio.2018.09.032

Kyker-Snowman E, Wieder WR, Frey S, Grandy AS (2019) Stoichiometrically coupled carbon and nitrogen cycling in the MIcrobial-MIneral Carbon Stabilization model (MIMICS-CN). Geosci Model Dev Discuss. https://doi. org/10.5194/gmd-2019-320

Ladd JN, Paul EA (1973) Changes in enzymic activity and distribution of acid-soluble, amino acid-nitrogen in soil during nitrogen immobilization and mineralization. Soil Biol Biochem 5:825-840. https://doi.org/10.1016/00380717(73)90028-X

Lambert J-F (2008) Adsorption and polymerization of amino acids on mineral surfaces: a review. Orig Life Evol Biosph 38:211-242. https://doi.org/10.1007/s11084-008-9128-3

Lavallee JM, Soong JL, Cotrufo MF (2020) Conceptualizing soil organic matter into particulate and mineral-associated forms to address global change in the 21 st century. Glob Change Biol 26:261-273. https://doi.org/10.1111/gcb. 14859

Lehmann J, Kleber M (2015) The contentious nature of soil organic matter. Nature 528:60-68. https://doi.org/10.1038/ nature 16069

Leinweber P, Reuter G (1992) The influence of different fertilization practices on concentrations of organic carbon and total nitrogen in particle-size fractions during 34 years of a soil formation experiment in loamy marl. Biol Fertil Soils 13:119-124. https://doi.org/10.1007/BF00337346

Li B, Ge T, Hill PW et al (2020a) Experimental strategies to measure the microbial uptake and mineralization kinetics of dissolved organic carbon in soil. Soil Ecol Lett. https:// doi.org/10.1007/s42832-020-0035-5

Li Z, Zeng Z, Tian D et al (2020b) The stoichiometry of soil microbial biomass determines metabolic quotient of nitrogen mineralization. Environ Res Lett 15:034005. https://doi.org/10.1088/1748-9326/ab6a26

Lin H-C, Huber JA, Gerl G, Hülsbergen K-J (2016) Nitrogen balances and nitrogen-use efficiency of different organic and conventional farming systems. Nutr Cycl Agroecosyst 105:1-23. https://doi.org/10.1007/s10705-016-9770-5

Lipson DA, Schmidt SK, Monson RK (1999) Links between microbial population dynamics and nitrogen availability in an alpine ecosystem. Ecology 80:1623-1631. https://doi. org/10.1890/0012-9658(1999)080[1623:LBMPDA]2.0. $\mathrm{CO} ; 2$

Litton CM, Raich JW, Ryan MG (2007) Carbon allocation in forest ecosystems. Glob Change Biol 13:2089-2109. https://doi.org/10.1111/j.1365-2486.2007.01420.x

Liu X, Lee Burras C, Kravchenko YS et al (2012) Overview of Mollisols in the world: distribution, land use and management. Can J Soil Sci 92:383-402

Lory JA, Russelle MP, Peterson TA (1995) A Comparison of Two nitrogen credit methods: traditional vs. difference. Agron J 87:648-651. https://doi.org/10.2134/agronj1995. 00021962008700040007x 
Ma Q, Wu L, Wang J et al (2018) Fertilizer regime changes the competitive uptake of organic nitrogen by wheat and soil microorganisms: an insitu uptake test using 13C, $15 \mathrm{~N}$ labelling, and 13C-PLFA analysis. Soil Biol Biochem 125:319-327. https://doi.org/10.1016/j.soilbio.2018.08. 009

Ma Q, Wen Y, Wang D et al (2020) Farmyard manure applications stimulate soil carbon and nitrogen cycling by boosting microbial biomass rather than changing its community composition. Soil Biol Biochem 144:107760. https://doi.org/10.1016/j.soilbio.2020.107760

Manzoni S, Taylor P, Richter A et al (2012) Environmental and stoichiometric controls on microbial carbon-use efficiency in soils. New Phytol 196:79-91. https://doi.org/10.1111/j. 1469-8137.2012.04225.x

McDaniel MD, Walters DT, Bundy LG et al (2020) Combination of biological and chemical soil tests best predict maize nitrogen response. Agron J 112:1263-1278. https://doi.org/ 10.1002/agj2.20129

Mikutta R, Kaiser K (2011) Organic matter bound to mineral surfaces: resistance to chemical and biological oxidation. Soil Biol Biochem 43:1738-1741. https://doi.org/10.1016/ j.soilbio.2011.04.012

Mikutta R, Kleber M, Jahn R (2005) Poorly crystalline minerals protect organic carbon in clay subfractions from acid subsoil horizons. Geoderma 128:106-115. https://doi.org/ 10.1016/j.geoderma.2004.12.018

Miltner A, Bombach P, Schmidt-Bruecken B, Kaestner M (2012) SOM genesis: microbial biomass as a significant source. Biogeochemistry 111:41-55. https://doi.org/10. 1007/s10533-011-9658-z

Moe LA (2013) Amino acids in the rhizosphere: from plants to microbes. Am J Bot 100:1692-1705. https://doi.org/10. 3732/ajb.1300033

Mooshammer M, Wanek W, Schnecker J et al (2012) Stoichiometric controls of nitrogen and phosphorus cycling in decomposing beech leaf litter. Ecology 93:770-782

Mooshammer M, Wanek W, Haemmerle I et al (2014a) Adjustment of microbial nitrogen use efficiency to carbon: nitrogen imbalances regulates soil nitrogen cycling. Nat Commun 5:3694. https://doi.org/10.1038/ncomms4694

Mooshammer M, Wanek W, Zechmeister-Boltenstern S, Richter A (2014b) Stoichiometric imbalances between terrestrial decomposer communities and their resources: mechanisms and implications of microbial adaptations to their resources. Front Microbiol 5:22. https://doi.org/10. 3389/fmicb.2014.00022

Moreau D, Bardgett RD, Finlay RD et al (2019) A plant perspective on nitrogen cycling in the rhizosphere. Funct Ecol 33:540-552. https://doi.org/10.1111/1365-2435.13303

Morrison EW, Frey SD, Sadowsky JJ et al (2016) Chronic nitrogen additions fundamentally restructure the soil fungal community in a temperate forest. Fungal Ecol 23:48-57. https://doi.org/10.1016/j.funeco.2016.05.011

Morrison EW, Pringle A, van Diepen LTA, Frey SD (2018) Simulated nitrogen deposition favors stress-tolerant fungi with low potential for decomposition. Soil Biol Biochem 125:75-85. https://doi.org/10.1016/j.soilbio.2018.06.027

Mueller CW, Weber PK, Kilburn MR et al (2013) Chapter One-advances in the analysis of biogeochemical interfaces: NanoSIMS to investigate soil microenvironments. In: Sparks DL (ed) Advances in agronomy. Academic Press, Cambridge, pp 1-46

Nannipieri P, Ascher-Jenull J, Ceccherini MT et al (2020) Beyond microbial diversity for predicting soil functions: a mini review. Pedosphere 30:5-17

Naylor D, Fansler S, Brislawn C et al (2020) Deconstructing the soil microbiome into reduced-complexity functional modules. MBio. https://doi.org/10.1128/mBio.01349-20

Noll L, Zhang S, Wanek W (2019a) Novel high-throughput approach to determine key processes of soil organic nitrogen cycling: gross protein depolymerization and microbial amino acid uptake. Soil Biol Biochem 130:73-81. https://doi.org/10.1016/j.soilbio.2018.12.005

Noll L, Zhang S, Zheng Q et al (2019b) Wide-spread limitation of soil organic nitrogen transformations by substrate availability and not by extracellular enzyme content. Soil Biol Biochem 133:37-49. https://doi.org/10.1016/j.soilbio. 2019.02.016

Norton J, Ouyang Y (2019) Controls and adaptive management of nitrification in agricultural soils. Front Microbiol. https://doi.org/10.3389/fmicb.2019.01931

Omoike A, Chorover J (2006) Adsorption to goethite of extracellular polymeric substances from Bacillus subtilis. Geochim Cosmochim Acta 70:827-838. https://doi.org/10. 1016/j.gca.2005.10.012

Parfitt RL, Theng BKG, Whitton JS, Shepherd TG (1997) Effects of clay minerals and land use on organic matter pools. Geoderma 75:1-12. https://doi.org/10.1016/S00167061(96)00079-1

Partavian A, Mikkelsen TN, Vestergård M (2015) Plants increase laccase activity in soil with long-term elevated CO2 legacy. Eur J Soil Biol 70:97-103. https://doi.org/10. 1016/j.ejsobi.2015.08.002

Paul EA (2016) The nature and dynamics of soil organic matter: Plant inputs, microbial transformations, and organic matter stabilization. Soil Biol Biochem 98:109-126. https://doi. org/10.1016/j.soilbio.2016.04.001

Phillips RP, Finzi AC, Bernhardt ES (2011) Enhanced root exudation induces microbial feedbacks to $\mathrm{N}$ cycling in a pine forest under long-term $\mathrm{CO} 2$ fumigation. Ecol Lett 14:187-194. https://doi.org/10.1111/j.1461-0248.2010. 01570.x

Phillips RP, Meier IC, Bernhardt ES et al (2012) Roots and fungi accelerate carbon and nitrogen cycling in forests exposed to elevated CO2. Ecol Lett 15:1042-1049. https://doi.org/ 10.1111/j.1461-0248.2012.01827.x

Pinu FR, Beale DJ, Paten AM et al (2019) Systems biology and multi-omics integration: viewpoints from the metabolomics research community. Metabolites 9:76. https://doi. org/10.3390/metabo9040076

Poirier V, Basile-Doelsch I, Balesdent J et al (2020) Organomineral interactions are more important for organic matter retention in subsoil than topsoil. Soil Syst 4:4. https://doi. org/10.3390/soilsystems4010004

Preece C, Peñuelas J (2020) A return to the wild: root exudates and food security. Trends Plant Sci 25:14-21. https://doi. org/10.1016/j.tplants.2019.09.010

Puissant J, Jones B, Goodall T et al (2019) The pH optimum of soil exoenzymes adapt to long term changes in soil $\mathrm{pH}$. Soil Biol Biochem 138:107601. https://doi.org/10.1016/j. soilbio.2019.107601 
Rashad M, Dultz S, Guggenberger G (2010) Dissolved organic matter release and retention in an alkaline soil from the Nile River Delta in relation to surface charge and electrolyte type. Geoderma 158:385-391. https://doi.org/10. 1016/j.geoderma.2010.06.007

Rasse DP, Dignac MF, Bahri H et al (2006) Lignin turnover in an agricultural field: from plant residues to soil-protected fractions. Eur J Soil Sci 57:530-538

Ren D, Madsen JS, Sørensen SJ, Burmølle M (2015) High prevalence of biofilm synergy among bacterial soil isolates in cocultures indicates bacterial interspecific cooperation. ISME J 9:81-89. https://doi.org/10.1038/ismej.2014.96

Reuter H, Gensel J, Elvert M, Zak D (2020) Evidence for preferential protein depolymerization in wetland soils in response to external nitrogen availability provided by a novel FTIR routine. Biogeosciences 17:499-514. https:// doi.org/10.5194/bg-17-499-2020

Rillig MC, Caldwell BA, Wösten HAB, Sollins P (2007) Role of proteins in soil carbon and nitrogen storage: controls on persistence. Biogeochemistry 85:25-44. https://doi.org/10. 1007/s10533-007-9102-6

Rinkes ZL, DeForest JL, Grandy AS et al (2014) Interactions between leaf litter quality, particle size, and microbial community during the earliest stage of decay. Biogeochemistry 117:153-168. https://doi.org/10.1007/s10533013-9872-y

Ros GH (2012) Predicting soil N mineralization using organic matter fractions and soil properties: a re-analysis of literature data. Soil Biol Biochem 45:132-135. https://doi.org/ 10.1016/j.soilbio.2011.10.015

Russell EJ, Russell EW (1950) Soil conditions and plant growth. Longmans, Green London

Samson M-E, Chantigny MH, Vanasse A et al (2020) Management practices differently affect particulate and mineral-associated organic matter and their precursors in arable soils. Soil Biol Biochem 148:107867. https://doi. org/10.1016/j.soilbio.2020.107867

Scheu S (2002) The soil food web: structure and perspectives. Eur J Soil Biol 38:11-20. https://doi.org/10.1016/S11645563(01)01117-7

Schimel JP, Bennett J (2004) Nitrogen mineralization: challenges of a changing paradigm. Ecology 85:591-602. https://doi.org/10.1890/03-8002

Schimel J, Schaeffer SM (2012) Microbial control over carbon cycling in soil. Front Microbiol. https://doi.org/10.3389/ fmicb. 2012.00348

Schmidt MWI, Torn MS, Abiven S et al (2011) Persistence of soil organic matter as an ecosystem property. Nature 478:49-56. https://doi.org/10.1038/nature10386

Schulten HR, Schnitzer M (1997) The chemistry of soil organic nitrogen: a review. Biol Fertil Soils 26:1-15. https://doi. org/10.1007/s003740050335

Sergaki C, Lagunas B, Lidbury I et al (2018) Challenges and approaches in microbiome research: from fundamental to applied. Front Plant Sci. https://doi.org/10.3389/fpls.2018. 01205

Sharma LK, Bali SK (2018) A review of methods to improve nitrogen use efficiency in agriculture. Sustainability 10:51. https://doi.org/10.3390/su10010051

Singh JS, Raghubanshi AS, Singh RS, Srivastava SC (1989) Microbial biomass acts as a source of plant nutrients in dry tropical forest and savanna. Nature 338:499-500. https:// doi.org/10.1038/338499a0

Singh M, Sarkar B, Biswas B et al (2016) Adsorption-desorption behavior of dissolved organic carbon by soil clay fractions of varying mineralogy. Geoderma 280:47-56. https://doi. org/10.1016/j.geoderma.2016.06.005

Sinha E, Michalak AM, Balaji V (2017) Eutrophication will increase during the 21 st century as a result of precipitation changes. Science 357:405. https://doi.org/10.1126/science. aan2409

Sinsabaugh RL (2009) Phenol oxidase, peroxidase and organic matter dynamics of soil. Soil Biol Biochem 42:391

Sinsabaugh RL, Turner BL, Talbot JM et al (2016) Stoichiometry of microbial carbon use efficiency in soils. Ecol Monogr 86:172-189

Six J, Elliott ET, Paustian K (2000) Soil structure and soil organic matter: II. A normalized stability index and the effect of mineralogy. Soil Sci Soc Am J 64:1042-1049

Six J, Frey SD, Thiet RK, Batten KM (2006) Bacterial and fungal contributions to carbon sequestration in agroecosystems. Soil Sci Soc Am J 70:555-569. https://doi.org/ 10.2136/sssaj2004.0347

Smith DR, Chapman MR (2010) Economical evolution: microbes reduce the synthetic cost of extracellular proteins. MBio. https://doi.org/10.1128/mBio.00131-10

Smith AP, Bond-Lamberty B, Benscoter BW et al (2017) Shifts in pore connectivity from precipitation versus groundwater rewetting increases soil carbon loss after drought. Nat Commun 8:1335. https://doi.org/10.1038/s41467-01701320-X

Sollins P, Spycher G, Glassman CA (1984) Net nitrogen mineralization from light- and heavy-fraction forest soil organic matter. Soil Biol Biochem 16:31-37. https://doi. org/10.1016/0038-0717(84)90122-6

Sollins P, Homann P, Caldwell BA (1996) Stabilization and destabilization of soil organic matter: mechanisms and controls. Geoderma 74:65-105

Sollins P, Swanston C, Kleber M et al (2006) Organic C and N stabilization in a forest soil: evidence from sequential density fractionation. Soil Biol Biochem 38:3313-3324

Sorensen PL, Clemmensen KE, Michelsen A et al (2008) Plant and microbial uptake and allocation of organic and inorganic nitrogen related to plant growth forms and soil conditions at two subarctic tundra sites in Sweden. Arct Antarct Alp Res 40:171-180. https://doi.org/10.1657/ 1523-0430(06-114)[SORENSEN]2.0.CO;2

St. Luce M, Whalen JK, Ziadi N, Zebarth BJ (2011) Chapter two-nitrogen dynamics and indices to predict soil nitrogen supply in humid temperate soils. In: Sparks DL (ed) Advances in agronomy. Academic Press, Cambridge, pp 55-102

Sterner RW, Elser JJ (2002) Ecological stoichiometry: the biology of elements from molecules to the biosphere. Princeton University Press, Princeton

Sulman BN, Phillips RP, Oishi AC et al (2014) Microbe-driven turnover offsets mineral-mediated storage of soil carbon under elevated CO 2. Nat Clim Change 4:1099-1102. https://doi.org/10.1038/nclimate2436

Tang YJ, Aristilde L (2020) Editorial overview: Analytical biotechnology in the era of high-performance omics, 
synthetic biology, and machine learning. Curr Opin Biotechnol 64:iii-vi. https://doi.org/10.1016/j.copbio. 2020.07.009

Thicke FE, Russelle MP, Hesterman OB, Sheaffer CC (1993) SOIL nitrogen mineralization indexes and corn response in crop rotations 1. Soil Sci 156:322-335

Torn MS, Kleber M, Zavaleta ES et al (2013) A dual isotope approach to isolate soil carbon pools of different turnover times. Biogeosciences 10:8067-8081. https://doi.org/10. 5194/bg-10-8067-2013

Tornkvist A, Liu C, Moschou PN (2019) Proteolysis and nitrogen: emerging insights. J Exp Bot 70:2009-2019. https://doi.org/10.1093/jxb/erz024

Treseder KK (2008) Nitrogen additions and microbial biomass: a meta-analysis of ecosystem studies. Ecol Lett 11:1111-1120. https://doi.org/10.1111/j.1461-0248.2008. 01230.x

Vempati RK, Kollipara KP, Stucki JW, Wilkinson H (1995) Reduction of structural iron in selected iron-bearing minerals by soybean root exudates grown in an in vitro geoponic system. J Plant Nutr 18:343-353. https://doi.org/10. 1080/01904169509364906

Vitousek P (1982) Nutrient cycling and nutrient use efficiency. Am Nat 119:553-572. https://doi.org/10.1086/283931

Vogel C, Mueller CW, Höschen C et al (2014) Submicron structures provide preferential spots for carbon and nitrogen sequestration in soils. Nat Commun 5:2947. https://doi. org/10.1038/ncomms3947

von Haden AC, Kucharik CJ, Jackson RD, Marín-Spiotta E (2019) Litter quantity, litter chemistry, and soil texture control changes in soil organic carbon fractions under bioenergy cropping systems of the North Central U.S. Biogeochemistry 143:313-326. https://doi.org/10.1007/ s10533-019-00564-7

Wade J, Waterhouse H, Roche LM, Horwath WR (2018) Structural equation modeling reveals iron (hydr)oxides as a strong mediator of $\mathrm{N}$ mineralization in California agricultural soils. Geoderma 315:120-129. https://doi.org/10. 1016/j.geoderma.2017.11.039

Wanek W, Mooshammer M, Blöchl A et al (2010) Determination of gross rates of amino acid production and immobilization in decomposing leaf litter by a novel $15 \mathrm{~N}$ isotope pool dilution technique. Soil Biol Biochem 42:1293-1302. https://doi.org/10.1016/j.soilbio.2010.04.001

Wang T, Tian Z, Tunlid A, Persson P (2020a) Nitrogen acquisition from mineral-associated proteins by an ectomycorrhizal fungus. New Phytol 228:697-711. https://doi.org/10. 1111/nph.16596

Wang X, Dijkstra FA, Yin L et al (2020b) Rhizosphere priming effects in soil aggregates with different size classes. Ecosphere 11:e03027. https://doi.org/10.1002/ecs2.3027

Warren CR (2019) Isotope pool dilution reveals rapid turnover of small quaternary ammonium compounds. Soil Biol Biochem 131:90-99. https://doi.org/10.1016/j.soilbio. 2019.01.004

Whalen JK, Bottomley PJ, Myrold DD (2000) Carbon and nitrogen mineralization from light- and heavy-fraction additions to soil. Soil Biol Biochem 32:1345-1352
Wickings K, Grandy AS (2011) The oribatid mite Scheloribates moestus (Acari: Oribatida) alters litter chemistry and nutrient cycling during decomposition. Soil Biol Biochem 43:351-358. https://doi.org/10.1016/j.soilbio.2010.10.023

Wieder WR, Grandy AS, Kallenbach CM et al (2015) Representing life in the Earth system with soil microbial functional traits in the MIMICS model. Geosci Model Dev 8:1789-1808. https://doi.org/10.5194/gmd-8-1789-2015

Wild B, Ambus P, Reinsch S, Richter A (2018) Resistance of soil protein depolymerization rates to eight years of elevated $\mathrm{CO} 2$, warming, and summer drought in a temperate heathland. Biogeochemistry 140:255-267. https://doi.org/ 10.1007/s10533-018-0487-1

Wild B, Li J, Pihlblad J et al (2019) Decoupling of priming and microbial $\mathrm{N}$ mining during a short-term soil incubation. Soil Biol Biochem 129:71-79. https://doi.org/10.1016/j. soilbio.2018.11.014

Xia L, Lam SK, Chen D et al (2017) Can knowledge-based N management produce more staple grain with lower greenhouse gas emission and reactive nitrogen pollution? A meta-analysis. Glob Change Biol 23:1917-1925. https:// doi.org/10.1111/gcb.13455

Xu H, Liu K, Zhang W et al (2020) Long-term fertilization and intensive cropping enhance carbon and nitrogen accumulated in soil clay-sized particles of red soil in South China. J Soils Sediments 20:1824-1833. https://doi.org/10.1007/ s11368-019-02544-8

Xyla AG, Sulzberger B, Luther GW et al (1992) Reductive dissolution of manganese(III, IV) (hydr)oxides by oxalate: the effect of $\mathrm{pH}$ and light. Langmuir 8:95-103. https://doi. org/10.1021/la00037a019

Yan M, Pan G, Lavallee JM, Conant RT (2020) Rethinking sources of nitrogen to cereal crops. Global Change Biol 26:191-199. https://doi.org/10.1111/gcb.14908

Yang L, Yu C, Zhang L et al (2020) Substrate availability affects the partitioning of $\mathrm{C}$ and $\mathrm{N}$ in glycine between plants and soil microorganisms. Arch Agron Soil Sci. https://doi.org/ 10.1080/03650340.2020.1714034

Yu Z, Zhang Q, Kraus TEC et al (2002) Contribution of amino compounds to dissolved organic nitrogen in forest soils. Biogeochemistry 61:173-198

Zhang X, Davidson EA, Mauzerall DL et al (2015) Managing nitrogen for sustainable development. Nature 528:51-59. https://doi.org/10.1038/nature15743

Zhang S, Zheng Q, Noll L et al (2019) Environmental effects on soil microbial nitrogen use efficiency are controlled by allocation of organic nitrogen to microbial growth and regulate gross $\mathrm{N}$ mineralization. Soil Biol Biochem 135:304-315. https://doi.org/10.1016/j.soilbio.2019.05. 019

Zhu B, Gutknecht JLM, Herman DJ et al (2014) Rhizosphere priming effects on soil carbon and nitrogen mineralization. Soil Biol Biochem 76:183-192. https://doi.org/10.1016/j. soilbio.2014.04.033

Publisher's Note Springer Nature remains neutral with regard to jurisdictional claims in published maps and institutional affiliations. 